\title{
A Queen-Mother at Work: On Handan Sultan and Her Regency During the Early Reign of Ahmed I*
}

\section{Faal Bir Valide Sultan: Handan Sultan ve I. Ahmed'in Hükümdarlığının Başlarındaki Naibeliği Üzerine}

\author{
Günhan Börekçi' (1)
}

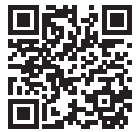

*I thank Pál Fodor, Jane Hathaway, Cankat and Elif Fatma Kaplan, Özlem Kumrular, Emese Muntán, Halit Serkan Simen and Cevat Sucu for their personal support and generous help during the preparation of this study. I remain grateful to my colleague Maurizio Arfaioli for his research assistance in the Venetian State Archives back in the mid-2000s, as well as for the transcriptions from the Italian ambassadorial dispatches cited below. Needless to say, any shortcomings in these passages entirely belong to me. I dedicate this article to the memory of my late mother, Zeynep Börekçi (1940-2011).

'Corresponding author/Sorumlu yazar: Günhan Börekçi (Visiting Prof.),

Central European University, Department of Medieval Studies, Budapest, Hungary

E-posta: borekcig@ceu.edu

ORCID: 0000-0003-2974-6749

\section{Submitted/Başvuru: 02.07.2020 \\ Revision Requested/Revizyon Talebi: 16.08.2020 \\ Last Revision Received/Son Revizyon: \\ 21.08.2020 \\ Accepted/Kabul: 23.08.2020}

Citation/Atıf: Borekci, Gunhan, "A QueenMother at Work: On Handan Sultan and Her Regency During the Early Reign of Ahmed I", Güneydoğu Avrupa Araştırmaları Dergisi, 34 (2020), s. 45-92.

https://doi.org/10.26650/gaad.20213403

\begin{abstract}
Handan Sultan (d. 1605), the Bosnian mother of Ahmed I (r. 1603-1617), has thus far remained an ambiguous political figure in Ottoman historiography. This article seeks to remedy this ambiguity by providing a detailed discussion of Handan Sultan's life, political career and various undertakings in the light of new historical evidence, as well as with respect to the related scholarly literature on early modern Ottoman royal women. Accordingly, by utilizing the unpublished letters of the contemporary Venetian ambassadors resident in Istanbul in conjunction with various Ottoman archival and narrative sources, this study examines first Handan Sultan's long years of concubinage in the harem of her husband, Mehmed III (r. 1595-1603), and then her queenmothership during the first two years of the sultanate of her teenage son, Ahmed I. Overall, as the first comprehensive biographical study on Handan Sultan, this article demonstrates that, contrary to the established scholarly opinion, Handan Sultan was a precursor regent queen-mother well before her famous successors, such as Kösem Sultan (d. 1651) and Turhan Sultan (d. 1683), played the same critical role in Ottoman dynastic and court politics in the seventeenth century.
\end{abstract}

Keywords: Handan Sultan, Queen-Mother, Regency, Ahmed I, Mehmed III, Favorite Concubine, Ottoman Dynasty, Biography

\section{öz}

I. Ahmed'in (salt. 1603-1617) Boşnak asıllı annesi Handan Sultan (öl. 1605), Osmanlı tarihyazımında hâlâ müphem bir siyasi kişilik olarak yer almaktadır. Bu makale, Handan Sultan'ın hayatını, siyasi kariyerini ve çeşitli faaliyetlerini hem yeni tarihsel kanıtların ışı̆̆ında, hem de erken modern Osmanlı hanedan kadınları hakkında mevcut akademik literatür çerçevesinde ayrıntıı bir şekilde tartışarak bu belirsizliği gidermeyi amaçlamaktadır. Bu minvalde İstanbul'da kâim çağdaş Venedik elçilerinin yayınlanmamış mektupları çeşitli Osmanlı arşiv ve anlatı kaynaklarılla birlikte kullanılarak, ilk önce Handan Sultan'ın eşi III. Mehmed'in (salt. 1595-1603) hareminde geçirdiği uzun 
cariyelik yılları, ardından ergenlik çağındaki oğlu I. Ahmed'in hükümdarlığının ilk iki senesindeki valide sultanlığı incelenmektedir. Sonuç olarak, Handan Sultan üzerine yapılmış ilk kapsamlı biyografik çalışma olan bu makale, yerleşmiş akademik görüşün aksine, Handan Sultan'ın öncü bir naibe valide sultan olduğunu ve onun 17. yüzyıl Osmanlı hanedan ve saray siyasetindeki bu önemli rolü, Kösem Sultan (öl. 1651) ve Turhan Sultan (öl. 1683) gibi meşhur haleflerinden çok daha evvel üstlendiğini göstermektedir.

Anahtar Kelimeler: Handan Sultan, Niyabet, Valide Sultan, I. Ahmed, III. Mehmed, Haseki Sultan, Osmanlı Hanedanı, Biyografi

Intriguingly, Handan Sultan (d. 1605) is still an elusive political figure in modern Ottoman historiography. It seems scholars have so far shown very limited interest in exploring the life and legacy of this early seventeenth-century dynastic matriarch of the House of Osman. Indeed, as of today, there exists not a single separate or extensive study which examines both Handan's long tenure as a concubine in the harem of her husband, Mehmed III (r. 1595-1603), and her short but crucial two-year queen-mothership during the early reign of her teenage son, Ahmed I (r. 1603-17). ${ }^{1}$

Such a dearth of scholarship about Handan Sultan is all the more striking considering that the past few decades have witnessed a significant expansion in not just the overall number and scope of thematic studies, but also the corpus of biography-oriented articles and books published on premodern Ottoman royal women in general, and queen-mothers in particular. ${ }^{2}$ However, as part of this burgeoning subfield of research in recent Ottoman historiography, no scholar has yet undertaken a complementary biographical study so as to

1 Even in the most frequently used biographical reference works for Ottoman history and its ruling elite, Handan Sultan is hardly mentioned. For example, in Brill's Encyclopedia of Islam and Türkiye Diyanet Vakfi's Islam Ansiklopedisi, which are periodically updated encyclopedias, and both are now accessible online as digital platforms, there is still no separate entry for Handan Sultan as opposed to several other Ottoman queenmothers. As for the who-is-who in Ottoman history compilations, her biography features but barely in more than one paragraph. Compare, e.g., Mehmed Süreyya, Sicil-i Osmanî, ed. Nuri Akbayar and Seyit Ali Kahraman, 6 vols. (Istanbul: Tarih Vakfı Yayınları 1996), vol. 1:14; Çağatay Uluçay, Padişahların Kadınları ve Kızları (Ankara: Türk Tarih Kurumu Yayınları, 1985 [2 $2^{\text {nd }}$ ed.]), 47; and Necdet Sakaoğlu, Bu Mülkün Kadın Sultanları (Istanbul: Alfa Yayınları, 2015 [revised ed.]), 300-301. For an evaluation of the existing few critical studies related to the queen-mothership of Handan Sultan, see below.

2 In this context, Leslie Peirce's The Imperial Harem: Women and Sovereignty in the Ottoman Empire (Oxford: Oxford University Press, 1993) was the ground-breaking work after which, particularly in the 2010s, several individual-oriented books have come out. Inter alia, see Lucienne Thys-Şenocak, Ottoman Women Builders: The Architectural Patronage of Hadice Turhan Sultan (Burlington, VT: Ashgate, 2007); Murat Kocaaslan, Kösem Sultan: Hayatı, Vakıfları, Hayır İşleri ve Üsküdar'daki Külliyesi (İstanbul: Okur Kitaplı̆̆ı, 2014); Betül İpşirli Argıt, Rabia Gülnuş Emetullah Sultan, 1640-1715 (İstanbul: Kitap Yayınevi, 2015); Özlem Kumrular, Kösem Sultan: Iktidar, Hırs, Entrika (İstanbul: Doğan Kitap, 2015) and eadem, Haremde Taht Kuranlar: Nurbanu ve Safiye Sultan, (İstanbul: Doğan Kitap, 2017); Erhan Afyoncu and Uğur Demir, Turhan Sultan (İstanbul: Yeditepe Yayınları 2015); Muzaffer Özgüleş, The Women Who Built the Ottoman World: Female Patronage and the Architectural Legacy of Gülnuş Sultan (London: I.B. Tauris, 2017); Pınar Kayaalp, The Empress Nurbanu and Ottoman Politics in the Sixteenth Century: Building the Atik Valide, (London: Taylor and Francis, 2018). Also see Ali Akyıldız, Haremin Padişahı Valide Sultan: Harem'de Hayat ve Teşkilat, (İstanbul: Timaş Yayınları, 2017) which is the first scholarly monograph on the office of queen-mother and its occupants in Ottoman history. For further related literature, see the next footnote. 
shed new light on Handan Sultan and/or stipulate a fresh comparative perspective regarding her historical standing vis-à-vis other, relatively better known Ottoman royal consorts and empresses of the so-called early modern era. In other words, unlike most of her sixteenthand seventeenth-century peers, notably Nurbanu, Safiye, Mahpeyker Kösem, Hadice Turhan and Emetullah Gülnuş Sultans, who have thus far received varying degrees of attention from modern scholars, Handan Sultan remains an ambiguous character in the shadows of history. ${ }^{3}$

The primary purpose of this article is to remedy this situation to a certain extent, by providing a detailed discussion of Handan's life and career trajectory in the light of new documentary evidence and with a focus on the events/moments that had marked her years of concubinage and queen-mothership, as well as on her political power and agency, actions and aspirations, factional struggles, and network of clients at the Ottoman imperial court in Istanbul. And it is my main contention that, contrary to the prevailing scholarly understanding, Handan Sultan was actually a precursor regent queen-mother long before her successors, especially Kösem Sultan and Turhan Sultan, played the same critical role in Ottoman dynastic and court politics in the ensuing decades of the crisis-ridden seventeenth century. ${ }^{4}$

Since the early 1990s, studies on the history of premodern Ottoman royal women have been fundamentally (re)shaped within the new revisionist framework that Leslie Peirce advanced in her seminal book, The Imperial Harem. In this pioneering work, Peirce assesses the case of Handan Sultan as part of her larger analysis of the increased political status and influence of the favorite concubine (haseki) and the queen-mother (valide sultan) within the Ottoman dynastic-imperial establishment by the turn of the seventeenth century. Here is how Peirce portrays Handan among her contemporary peers:

3 On these mentioned royal mothers, in addition to the works cited above, see Ettore Rossi, "La Sultana Nûr Bânû (Cecilia Venier-Baffo) moglie di Selim II (1566-1574) e madre di Murad III (1574-1595)," Oriente Moderno 11 (1953), 433-441; Benjamin Arbel, “Nur Banu (c. 1530-1583): A Venetian Sultana?," Turcica 24 (1992), 241-259; Susan A. Skilliter, "Three Letters from the Ottoman 'Sultana' Safiye to Queen Elizabeth I," in Documents from Islamic Chanceries, ed. Samuel M. Stern (Oxford: Cassier 1965), 119-235; Maria Pia Pedani, "Safiye's Household and Venetian Diplomacy," Turcica 32 (2000), 9-32; Baki Tezcan, "The Debut of Kösem Sultan's Political Career," Turcica 40 (2008), 347-59; Recep Dündar, “Kıbrıs'ta Sultan Murad Han'ın Validesine (Kösem Sultan) Ait Mülk Çiftlikler," Karadeniz Araştırmaları: Balkan, Kafkas, Doğu Avrupa ve Anadolu Incelemeleri Dergisi 35 (2012), 111-124; İsmail Kıvrım, “17. Yüzyılda Bir Valide Sultanın Günlük Hayatı: Vâlide Hadîce Turhan Sultan,” History Studies 5/2 (2013), 243-262; Özer Küpeli, “Kösem Sultan'a Ait Bir Muhallefat Kaydı," Cihannüma: Tarih ve Coğrafya Araştırmaları Dergisi 1/2 (2015), 131-143; Yusuf Sağır, “Vâlide Turhan Sultan'ın Muhallefâtı," Çanakkale Araştırmaları Türk Yıllığı 20 (2016), 265-328; and Betül İpşirli Argıt, "A Queen-mother and the Ottoman Imperial Harem: Rabia Gülnuş Emetullah Valide Sultan (1640-1715)," in Concubines and Courtesans: Women and Slavery in Islamic History, ed. Matthew S. Gordon and Kathryn A. Hain (Oxford: Oxford University Press 2017), 207-224.

4 I had previously discussed some aspects of Handan Sultan's concubinage and regency in my doctoral dissertation and in an article published in Turkish: "Factions and Favorites at the Courts of Ahmed I (r. 1603-1617) and his Immediate Predecessors" (PhD. diss., Ohio State University, 2010), and "İnkırâzın Eşiğinde Bir Hanedan: III. Mehmed, I. Ahmed, I. Mustafa ve 17. Yüzyıl Osmanlı Siyasî Krizi," Dîvân Disiplinlerarası Çalışmalar Dergisi 26 (2009), 45-96. This present study is a revised and expanded version of my earlier findings and arguments. 
Handan Sultan is a pale figure in this period of colorful women. Her inferior status as valide sultan was no doubt a result, in part at least, of her inferior status as concubine; Mehmed [III] had elevated none of his concubines to the status of haseki, and so Handan was deprived of the kind of recognition enjoyed by Nurbanu and Safiye before their sons' sultanates. Furthermore, Handan died two years after her fourteen-year-old son Ahmed I took the throne, and therefore did not have much opportunity to develop an influential presence as valide sultan. In reaction to his grandmother Safiye's domination of his father, Ahmed appears to have deliberately downplayed the valide sultan's role $\left[\ldots . .{ }^{5}\right.$

As I will elaborate below, Peirce has missed a few but critical points in her otherwise much enlightening discussion of Handan Sultan in the related chapters of her book. At this point suffice it to say that Mehmed III had favorite concubines and Handan was most likely one of them, and that she did have a prominent presence at the court of her young son as the new queen-mother, succeeding the all-powerful Safiye Sultan.

In this regard, Baki Tezcan is the only other notable historian who, in one of his articles, has investigated the problem of regency in the context of sultanic decision-making during the early reign of Ahmed I, and accordingly touched upon Handan's queen-mothership. ${ }^{6}$ In his study, Tezcan delves into the published contemporary Ottoman chronicles and European ambassadorial reports in order to first delineate Handan's possible role in the expulsion of Safiye Sultan from the imperial harem, a truly remarkable event that took place in the first month of Ahmed's sultanate. After meticulously reviewing these sources, Tezcan reaches the conclusion that it is impossible to ascertain whether this decision was taken by Handan Sultan as regent, or it was rather Ahmed's own discretion in reaction to his paternal grandmother's overwhelming control over his late father, as also indicated by Peirce in her above remarks. Nonetheless, in the rest of his analysis, Tezcan insightfully observes that Mustafa Efendi, Ahmed's long-time tutor since his princely years, played a critical role in politically significant decisions at the sultan's court until his demise in around 1608. In other words, he suggests that Mustafa Efendi acted as de facto regent of Ahmed I before any other person, such as his mother, Handan Sultan, or his first grand vizier, Yavuz Ali Pasha, could fill that role.

While I agree with Tezcan on Mustafa Efendi's such position and power, I question his (and Peirce's) assertion that Handan Sultan had no visible or significant political role at Ahmed l's court. Rather, I would contend that she should be considered a co-regent with Mustafa Efendi from the beginning of her young son's sultanate in December 1603 until her early death in November 1605. Indeed, the unpublished dispatches of the contemporary Venetian ambassadors (It. baili; singular bailo) resident in Istanbul reveal much crucial

$5 \quad$ Peirce, The Imperial Harem, 127.

6 Baki Tezcan, "The Question of Regency in the Ottoman Dynasty: The Case of the Early Reign of Ahmed I," Archivum Ottomanicum 25 (2008), 185-98 [published in 2009]. 
information about Handan Sultan, testifying to her political power and status as the queenmother regnant. ${ }^{7}$

Based on these Italian archival sources, which were not utilized by Peirce and Tezcan in their mentioned studies, I would further argue that Ali Pasha was in effect Handan's client and that, as grand vizier, he was empowered to act both on her and her son's behalf within the newly configured power relations at the sultan's court. Not only Handan and Ali were both of Bosnian origin, but they also knew each other well before Ahmed l's enthronement, two important points often overlooked by scholars. ${ }^{8}$ That is to say, they had a mutual acquaintance going back to Manisa, the provincial capital of Saruhan, where Ahmed's father Mehmed III had served as princely governor for over a decade (1584-95). During that period, Handan was an esteemed concubine of Mehmed and gave birth to Ahmed in 1590 (and possibly to other children by her husband), whereas Ali served as the prince's sword-bearer, a prestigious position which he kept six more years after Mehmed III's enthronement in 1595. Overall, both their shared ethno-regional background (known as cins in Ottoman political culture) and their long-time membership in Mehmed IIl's princely/royal household inform us about a close patron-client relationship between Handan Sultan and Yavuz Ali Pasha, as well as explain their selection of several new court and government functionaries from Bosnian or Balkan origins in the first critical months of Ahmed's sultanate.

Accordingly, I hereby pursue two interrelated goals: On one hand, a renewed biographical discussion of Handan Sultan with an emphasis on those hitherto overlooked and/or poorly understood aspects of her political life and career; and on the other, a re-evaluation of the question of Ahmed l's regents as initially laid out by Tezcan. As we shall see, when scrutinized in the light of new historical evidence, Handan was neither a pale woman nor an uninfluential queen-mother as she came to be portrayed. On the contrary, as I have already indicated, she was a pioneering figure in the sense that her regency of Ahmed I set an example for future queen-mothers, particularly during the first half of the seventeenth century, a highly turbulent period which witnessed not just the coming of a series of exceedingly youthful sultans to the throne, but also an empire-wide general crisis under the exigencies of multi-front long wars,

7 For the resident Venetian ambassadors in the Ottoman capital, see Carla Coco and Flora Manzonetto, Baili veneziani alla Sublime Porta: storia e caratteristiche dell'ambasciata veneta a Costantinopoli (Venice: Stamperia di Venezia, 1985) and Eric Dursteler, "The Bailo in Constantinople: Crisis and Career in Venice's Early Modern Diplomatic Corps," Mediterranean Historical Review 16/2 (2001), 1-30. On the importance of Venetian ambassadorial dispatches and reports in studying Ottoman political history, see Elisabetta Borromeo, "Le relazioni degli ambasciatori veneziani presso la Porta Ottomana," Miscellanea di storia delle esplorazioni 19 (1994), 125-154; Eric Dursteler, “Describing or Distorting the "Turk"?: The Relazioni of the Venetian Ambassadors in Constantinople as Historical Source," Acta Histriae 19/1-2 (2011), 231-248 and Emrah Safa Gürkan, "Fonds for the Sultan: How to Use Venetian Sources for Studying Ottoman History," News on Rialto 32 (2013), 22-28.

8 To my knowledge, Maria Pia Pedani-Fabris, "Veneziani a Costantinopoli alla fine del XVI secolo," Quaderni di Studia Arabi 15 (1997), 67-84 (at 84), was the first scholar to indicate Handan's ethnic-regional origin as Bosnian. I will return to this point with further details. 
incessant military revolts, chronic financial difficulties, ubiquitous social disturbances, and intense factionalism within the imperial court and the royal family. ${ }^{?}$

But before we further proceed, let's check the current state of the field of Ottoman studies with respect to the general topic of regency. Over a decade ago, in his article noted above, Tezcan had pointed out to the absence of research on the question of regency (or lack thereof) in the Ottoman dynastic establishment over its 600-year history. ${ }^{10}$ Regrettably, his observation still holds true. Despite the fact that there were quite a number of Ottoman sultans who took the throne when they were underage, no scholarly monograph exists on this important historical problem. Nevertheless, thanks to the ever-expanding literature on premodern Ottoman history in general, and seventeenth-century queen-mothers in particular, we are now in a better position to postulate some more specific perspectives.

Most notably, in her aforementioned seminal book, Peirce has analyzed the changing historical roles of royal women, especially the queen-mother and the favorite concubine, and shown that their increased influence by the late sixteenth century was directly related to significant changes in the organization of the sultan's household, as well as in the principles that defined the Ottoman dynastic establishment, between the reigns of Süleyman I (r. 1520-66) and Murad III (r. 1574-95). Against the sexist vilification of these royal women as usurpers of political power, as long been done in conventional historiography under the rubric of "Sultanate of Women," Peirce emphasizes their gradually augmented as well as institutionalized political power over time, particularly with respect to the critical issues of perpetuating the Ottoman dynasty, preserving the political order centered on the sultan and crown princes, and sustaining a powerful image of the House of Osman. In this context, Peirce underlines two major changes regarding the status of the valide sultan and her historical roles:

1. In the late sixteenth century, when the multiple households of the Ottoman family once spread across the provinces were consolidated under one single royal household at Topkapı Palace, the queen-mother became the dynastic matriarch of the House of Osman, and in this capacity she began to exert a more direct and personal influence over her reigning son and the business of rule;

2. During the first half of the seventeenth century (i.e., the era of youthful sultans), she assumed further novel functions in dynastic and imperial affairs, the most important one being the role of regent based on her traditional maternal role as the chief guardian/political mentor of her son(s). ${ }^{11}$

9 At their accessions, Ahmed's two sons, Osman II (r. 1618-22) and Murad IV (r. 1623-40), were fourteen and eleven years old, respectively, while his grandson, Mehmed IV (r. 1648-87), was only seven years old. On the $17^{\text {th }}$-century Ottoman imperial crisis, see in particular Suraiya Faroqhi, "Crisis and Change," in An Economic and Social History of the Ottoman Empire, Halil İnalcık with Donald Quataert (Cambridge: Cambridge University Press, 1997), 411-636.

10 Tezcan, "The Question of Regency," 185.

11 Peirce, The Imperial Harem, esp. 91-112 and 229-265. 
In the latter framework, Peirce considers the cases of three royal mothers, namely, Halime, ${ }^{12}$ Kösem and Turhan Sultans, and discusses how they took leading roles in their sons' government. ${ }^{13}$ Tezcan, on the other hand, highlights the importance of the royal preceptor especially in the virtual absence of a valide sultan, as was the sole case under Osman II ( $r$. 1618-22) in this period. According to Tezcan, for Osman's mother Mahfiruz had passed away before he took the throne at the age of fourteen, his tutor Ömer Efendi, formerly a madrasa professor and a preacher, functioned as de facto regent of the teenage sultan, in a similar way Mustafa Efendi had previously done for Ahmed I or the all-powerful Chief Jurisprudent (Mufti) Feyzullah Efendi would much later do for Mustafa II (r. 1695-1703). ${ }^{14}$

It should be emphasized that the limited number and scope of available Ottoman primary sources present a great obstacle for any scholar who tries to unearth more specific information about a regent's daily role and actions at the sultan's court during this crisis-ridden era. For instance, as Peirce also points out, contemporary chroniclers do not use a term like "regency" in their description of these periods in which queen-mothers took charge or, for that matter, one can scarcely find in their narratives a detailed account of how a valide sultan actually ruled on behalf of her son. Luckily, there exists some archival documentation that sheds partial light on these regents' direct involvement in the business of state and its related decision-making processes. Particularly telling in this respect are the letters and petitions which both Kösem Sultan and Turhan Sultan exchanged with the government viziers and other court officials concerning several diverse topics and problems, such as the health and outdoor activities of the sultan, royal counseling, the distribution of the royal largess, appointments and dismissals in offices, salary payments, revenue assignments, budget deficits, provisioning of the imperial army and navy for war, and suppression of rebellions. ${ }^{15}$

12 Halime Sultan was the mother of Mustafa I (r. 1617-18; 1622-23), but she has long remained anonymous in historiography. Back in 2009, during my research for an article, I discovered that her name was recorded as such in an overlooked genealogy of the Ottoman sultans, which also correctly lists all the known queen-mothers until the late $19^{\text {th }}$ century: Silsile-nâme-i Âl-i 'Osmân, Milli Kütüphane, MS 06 Hk 11/3. However, at that time, I had hesitated to openly use this name in my published study for it was a unique reference. Börekçi, "İnkırâzın Eşiğinde Bir Hanedan," p. 58, n. 28. Since then, to my knowledge, no contradictory historical information has come out to modify my initial identification. Besides, after once more thoroughly examining this unpublished genealogical work, I now think that it is a reliable source, a point which I did not explicitly make in my article. Hence, in this study, I refer to Halime by her previously unknown name, with the hope that future studies will confirm it beyond any doubt.

13 Peirce, The Imperial Harem, 248-258.

14 Tezcan, "The Question of Regency;" and idem, The Second Ottoman Empire: Political and Social Transformation in the Early Modern World (Cambridge: Cambridge University Press, 2010), 118-128. Also see Rifa'at Abou-el-Haj, “The Narcissism of Mustafa II (1695-1703): A Psychohistorical Study," Studia Islamica 40 (1974), 115-131 and Tahir Sevinç, “Il. Mustafa'nın İktidar Mücadelesi ve 1703 Edirne İsyanıyla Tahttan İndirilmesi," Osmanlı Mirası Araştırmaları Dergisi 4/9 (2017), 25-42.

15 The majority of the correspondences of Kösem Sultan and Turhan Sultan has been identified and published by Halil İnalcık, Devlet-i ‘Aliyye: Osmanlı Imparatorluğu Üzerine Araştırmalar-II: Tagayyür ve Fesad (1603-1656): Bozuluş ve Kargaşa Dönemi, ed. Emre Yalçın (İstanbul: Türkiye İş Bankası Kültür Yayınları, 2014), 371-470, and Afyoncu and Demir, Turhan Sultan, 221-355, respectively. 
According to the contemporary Venetian ambassadors present in Istanbul, Handan Sultan had similarly communicated with the incumbent pashas of her son's government. But no example of her such correspondence has been identified so far. Whatever she had written or exchanged along these lines are either still waiting in the archives and manuscript libraries to be found or simply lost to history. This absence of documentary evidence is no doubt one of the chief reasons why scholars have failed to describe Handan as a regent queen-mother like Kösem and Turhan.

That said, in general Ottoman historiography, Kösem Sultan has long been depicted as the most powerful and influential valide sultan, mainly for her active regency lasted for a total of two decades (1623-32/1640-51) and under three sultans, namely, her sons Murad IV (r. 1623-40) and ibrahim (r. 1640-48), and her grandson Mehmed IV (r. 1648-87), while her entire political career, started as being a haseki of Ahmed I in the early 1600 s, stretched over 45 years. ${ }^{16}$ However, as Erhan Afyoncu and Uğur Demir have recently shown, Kösem's rivalsuccessor, Turhan Sultan, was equally if not a more remarkable regent queen-mother. After Kösem was brutally killed in 1651 during a palace coup led by none other than Turhan and her court faction, she swiftly took over the regency of her nine-year-old Mehmed IV, and then energetically ruled on his behalf for many years to come. When she died of natural causes in 1683 , Turhan Sultan had been queen-mother for an uninterrupted period of 35 years, a record in Ottoman history. Perhaps more importantly, it was during her long tenure that the Ottomans had finally had some relief from the political, military and socio-economic maelstroms of this so-called general crisis era, thanks to the effective administration, successful reforms, and at times draconian measures of the Köprülü-family pashas whom she had initially empowered and supported as grand viziers. ${ }^{17}$

In a similar vein, Betül İpşirli Argıt has recently demonstrated that Gülnuş Sultan, the mother of Mustafa II and Ahmed III (r. 1703-30), was in fact another queen-mother of great importance in the late seventeenth and early eighteenth centuries. According to Ipşirli Argit, upon Turhan Sultan's death in 1683, Gülnuş became the sole authority in the imperial harem, and her political power and influence only grew bolder under the sultanates of her two sons. Indeed, from 1695 until her death in 1715, Gülnuş Sultan acted as one of the chief royal advisors, a power-broker in contemporary court politics as well as a key intermediary agent of diplomacy, as exemplified by her personal involvement and correspondence in the traffic of the diplomatic relations and negotiations during the so-called Great Northern War

16 Kösem's early career has been thoroughly examined by Tezcan, "The Debut of Kösem Sultan's Political Career." Among the studies discussing her queen-mothership and regency, see in particular İnalcık, Devlet-i 'Aliyye: Osmanlı Imparatorluğu Üzerine Araştırmalar-II, 187-206 and 243-274; and Feridun Emecen, Imparatorluk Çağının Osmanlı Sultanları-II: II. Selim'den Sultan Ibrâhim'e (1566-1648) (İstanbul: ISAM Yayınları, 2016), 251317 and 321-355, chapters, "IV. Murâd” and “ibrâhim, respectively. Peirce, The Imperial Harem, 248.

17 See Afyoncu and Demir, Turhan Sultan. 
(1700-21) between Russia and Sweden, a conflict to which the Ottoman Empire was drawn as an ally of the latter. ${ }^{18}$

All in all, when juxtaposed to these impressive long careers and various political undertakings of Kösem, Turhan and Gülnuş Sultans, Handan Sultan might appear a much less important figure. But we should not judge Handan by such high-profile successors of hers, at least not without first locating and analyzing as many existing historical sources and accounts as possible pertaining to her life and queen-mothership. Only after doing so, we can develop a more nuanced and proper understanding of her relative standing among her peers in early modern Ottoman history or, for that matter, other contemporary regents/queens in different Eurasian royal courts. So, let's turn our attention to Handan now and look at her case more closely.

\section{A Bosnian Slave Girl Turns Concubine}

Until the 1580s, as is known, the Ottoman royal family had traditionally sent out their princes to select provinces as governors in order to prepare them for a possible sultanate in the future. ${ }^{19}$ In the sixteenth century, such a provincial appointment (known as sancağa çıkma) was typically arranged soon after the prince was circumcised at around the age of fifteen at a festival organized by the royal family and celebrated by the public in the capital. ${ }^{20}$ Apart from the fact that male circumcision was a religious obligation for all Muslims, the circumcision of an Ottoman prince marked the beginning of the political and sexual maturity of a prospective Ottoman ruler. Moreover, Ottoman royal circumcision festivals, and thus the celebration of a prince's political coming of age, had important symbolic functions, especially with respect to sustaining powerful dynastic and imperial imagery. ${ }^{21}$ In this regard, it was customary among the high elite to give the departing prince concubines as potential mothers. ${ }^{22}$

18 See İpşirli Argıt, Rabia Gülnuş Emetullah Sultan, and eadem, "A Queen-mother and the Ottoman Imperial Harem."

19 On these provincial governorships of Ottoman princes, see İsmail Hakkı Uzunçarşılı, "Sancağa Çıkarılan Osmanlı Şehzadeleri," Belleten 156 (1975), 659-696; Metin Kunt, “A Prince Goes Forth (Perchance to Return)," in Identity and Identity Formation in the Ottoman World: A Volume of Essays in Honor of Norman Itzkowitz, ed. Baki Tezcan and Karl K. Barbir (Madison: University of Wisconsin Press, 2007), 63-71 and Feridun Emecen, “Osmanlı Şehzadeleri ve Taşra İdaresi," in Selçukludan Cumhuriyete Şehir Yönetimi, ed. Erol Özvar and Arif Bilgin (İstanbul: Türk Dünyası Belediyeler Birliği, 2008), 99-112.

20 On the $15^{\text {th }}$ - and $16^{\text {th }}$-century Ottoman royal festivals, see Ali Haydar Bayat, “Fâtih'in Tertip Ettiği Sünnet Şenlikleri (Sûr-i Hümâyunlar)," Kubbealtı Akademi Mecmuası 3 (1983), 51-62; idem, "Edirne Sarayı Sosyal Hayatından Bir Kesit: 861/1457 Sünnet Şenliği," in I. Edirne Sarayı Sempozyumu Bildirileri, ed. Ender Bilar (Edirne: Trakya Üniversitesi Rektörlüğü Yayınları, 1996), 62-75; idem, “Kanûnî’nin Tertip Ettiği Şenliklerden 1539 Sûr-i Hümâyûnu," in Uluslararası Dördüncü Türk Kültürü Kongresi Bildirileri, ed. Azize Aktaş Yaşa and İmran Baba (Ankara: Atatürk Kültür Merkezi Başkanlığı, 2000), 3:111-134 and 461; Zeynep Yelçe, "Evaluating Three Imperial Festivals: 1524, 1530 and 1539," in Celebration, Entertainment and Theatre in the Ottoman World, ed. Suraiya Faroqhi and Arzu Öztürkmen (Calcutta: Seagull Books, 2014), 71-109 and Kaya Şahin, "Staging an Empire: An Ottoman Circumcision Ceremony as Cultural Performance," American Historical Review 123/2 (2018), 463-492.

21 In this context, see in particular Rhoads Murphey, Exploring Ottoman Sovereignty: Tradition, Image and Practice in the Ottoman Imperial Household, 1400-1800 (London: Continuum, 2008), 175-205.

22 Hedda Reindl-Kiel, "Power and Submission: Gifting at Royal Circumcision Festivals in the Ottoman Empire (16 $6^{\text {th }}-18^{\text {th }}$ Centuries)," Turcica 41 (2009), 37-88, provides an enlightening analysis of the gift-giving custom and the types of gifts at the Ottoman circumcision festivals. 
Handan was one such concubine. She seems to have joined the harem of her future husband, Prince Mehmed (III), sometime between the ostentatious 56-day festival held in May-July 1582 in honor of the prince's circumcision at the age of sixteen and his departure for Manisa in mid-December 1583. ${ }^{23}$ Writing in January 1604, the Venetian bailo Francesco Contarini notes that Handan was of Bosnian origin and she was a slave girl in the household of the governor-general of Rumeli, Mehmed Pasha, who happened to be the surgeon (hence his nickname, Cerrah) who had circumcised Prince Mehmed. On account of her beauty, the pasha gave Handan to the prince on his departure for Manisa. ${ }^{24}$

At the time, Mehmed Pasha was a brand new vizier in the imperial council, as well as a new royal son-in-law, having recently married Gevherhan Sultan, a sister of Murad III and thus an aunt of Prince Mehmed. ${ }^{25}$ Such a 'gift' by a high-ranking vizier to the departing prince was surely intended to solidify the former's political alliance with the dynasty. ${ }^{26}$ In fact, most

23 On this festival, see Derin Terzioğlu, "The Imperial Circumcision Festival of 1582: An Interpretation," Muqarnas 12 (1995), 84-100 and Gülsüm Ezgi Korkmaz, "Sûrnâmelerde 1582 Şenliği” (Unpublished MA thesis, Bilkent Üniversitesi, 2004.)

24 Archivio di Stato di Venezia (ASVe), Senato, Dispacci Costantinopoli (SDC), filza 58, fol. 269v (dated January 17, 1604): “La presente Regina è di natione Bossinese, fu prima schiava di Mehemet Girà quando era Begleirbei della Grecia et poi donata per la sua gran bellezza a Sultan Mehemet quando andò al Sanzaccato di Amasia [i.e., Manisa]." According to Seyyid Lokman, the contemporary court historiographer, Mehmed Pasha was the deputy of the grand admiral at this time, while the governor-general of Rumeli was Damad Ibrahim Pasha, who would later become grand vizier three times under Mehmed III. Seyyid Lokman, Zübdetü't-tevârîh, Türk İslam Eserleri Müzesi, MS 1973, fol. 98r. Two contemporary authors, Selaniki and Ferâhî, similarly have Mehmed Pasha as a vizier at the court and İbrahim Pasha as the governor-general of Rumeli. Tarih-i Selânikî, ed. Mehmet İpşirli, 2 vols. (Ankara: Türk Tarih Kurumu, 1999 [2 ${ }^{\text {nd }}$ edition]), 1:134-135 [henceforth, Tarih-i Selânikî] and Mehmet Özdemir, Ferâhî, Sûrnâme: Bir Özge Âlem, Osmanlı Pâyitahtında 1582 Şenliği (Ankara: Grafiker Yayınları, 2016), 158, 223 and 234-235. The Venetian bailo Paolo Contarini, in his relazione of 1583, mentions Cerrah Mehmed Pasha as the fourth-ranking vizier in the government. Eugenio Albèri (ed.), Le relazioni degli ambasciatori veneziani al senato durante il secolo decimosesto, serie 3, vol. III (Florence: Società editrice fiorentina 1855), 241. According to Yusuf Halaçoğlu, s.v. "Cerrah Mehmed Paşa," Diyanet Islam Vakfı Ansiklopedisi [hereafter DiA], 7:415, Mehmed Pasha replaced his namesake Boyalı/Nişancı Mehmed Pasha as the fourth vizier in March 1582.

25 This marriage of Gevherhan Sultan must have taken place soon after the death of her first husband, Piyale Pasha, in January 1578. Baki Tezcan, "Searching for Osman: A Reassessment of the Deposition of the Ottoman Sultan Osman II (1618-1622)" (PhD diss., Princeton University, 2001), 343, n. 132, discusses Mehmed Pasha's marriage to Gevherhan and, at some length, his ethnic origins which remain an enigma. Whereas Uluçay, Padişahların Kadınları ve Kızları, 41-42; Sakaoğlu, Bu Mülkün Kadın Sultanları, 275-276; and İdris Bostan, “Esaretten Vezarete Bir Osmanlı Kaptanıderyası: Piyale Paşa," in Piyale Paşa Camii: 2005-2007 Restorasyonu, ed. Baha Tanman and İdris Bostan (İstanbul: Gürsoy Grup Kültür Yayınları, 2011) 13-37 (at 39) are mistaken when they note that Gevherhan Sultan married Nişancı/Boyalı Mehmed Pasha after Piyale Pasha's death.

26 According to Niclas Haunolth, who wrote a detailed eyewitness account of the 1582 festival, Mehmed Pasha presented his gifts to Murad III and Prince Mehmed on June 5, 1582. The pasha's gifts were estimated to be worth 15,000 ducats in total and included horses, fabrics, silverware items and a few slaves. For a Turkish translation of this account, see Johannes Leunclavius, Türk Milletinin Tarihi, trans. Türkis Noyan (İstanbul: Yeditepe Yayınları, 2019), 430-536 [Mehmed Pasha's gifts are noted at 443]. An undated register of gifts from this festival reveals that Mehmed Pasha apparently submitted a few more items, such as two illustrated books and a golden dagger. Topkapı Palace Museum Archives (TSMA), D. 7856/2, fol. 1v. This register is analyzed by Reindl-Kiel, "Power and Submission." For a comprehensive list of the gifts presented by the Ottoman ruling elite, courtiers and guilds to Murad III, Prince Mehmed, and his mother Safiye Sultan, see Özdemir, Ferâhî, Surnâme, 71-109. 
people believed that Mehmed Pasha's promotion from agha of the Janissaries to governorgeneral of Rumeli a year ago was due to the political power of his wife at the court of Murad III. ${ }^{27}$ During Mehmed III's reign, Mehmed Pasha would continue to serve as a government vizier, and even briefly occupy the office of grand vizierate for about 9 months (April 1598-January 1599), ${ }^{28}$ while Gevherhan Sultan would similarly remain an influential political figure in court circles, a position which apparently enabled her to keep in touch with Mehmed III's sons and their mothers, as well. ${ }^{29}$

Indeed, soon after his succession, young Ahmed I wanted to express his gratitude to the Gevherhan-Mehmed couple for the role they had played in bringing his parents together, a generous act which turned out to be a blessing for him. By then, however, Cerrah Mehmed Pasha was old and ailing; he died on January 9, 1604. Ahmed therefore honored the late pasha's wife. Contarini further records that "having remembered this [i.e., his mother's background], he sent the sultana [Gevherhan] a thousand gold coins and a sable robe with many other gifts as a sign of welcome, since she had been the origin of his good fortune and of the greatness in which at present he found himself." ${ }^{30}$ Sultan Ahmed would later name his firstborn daughter Gevherhan to further mark his great-great-aunt's role in his life. ${ }^{31}$

While these few details shed light on the beginnings of Handan's future career as a royal woman in the Ottoman world, her earlier life still remains in mystery due to the lack of any information about her birth date, family background and childhood. We likewise do not know when and how she ended up as a slave girl in the household of Mehmed Pasha and Gevherhan Sultan. For the moment, we can only make an informed guess about her age based on a better known contemporary case: the aforementioned Safiye Sultan was an Albanian girl of thirteen

27 Tarih-i Selânikî, 1:127. Also noted by Tezcan, "Searching for Osman," 343, n. 132, in the same context.

28 For a brief contemporary biography of Cerrah Mehmed Pasha, see Mehmed bin Mehmed, Ta'rîh-i Âl-i 'Osmân, in Abdurrahman Sağırlı, “Mehmed b. Mehmed Er-Rumî (Edirneli)'nin Nuhbetü't-tevârîh ve'l-ahbâr'ı ile Târîh-i Âl-i Osmân'ının Metni ve Tahlilleri," (PhD diss., İstanbul Üniversitesi, 2000), 1-148 [Part II] at 31 [hereafter Mehmed bin Mehmed, Tarih].

29 Gevherhan Sultan was born in 1544 and died in the 1620s. Her mother was almost certainly Nurbanu Sultan (d. 1583), the favorite concubine of Selim II (r. 1566-74). For further remarks about her life and political influence during the reigns of Murad III and Mehmed III, see Kumrular, Haremde Taht Kuranlar, 16, 66-67, 117-118, 174, 180, 187 and 267. On her relationship with Handan Sultan and Ahmed I, see below.

30 ASVe, SDC, filza 58, fol. 269v (dated January 17, 1604). A register preserved in the Topkapı Palace Museum Archives gives further details of the gifts Gevherhan Sultan received from her great grand-cousin. At the beginning of this register, there are records of the furs and robes of honor sent by the new sultan to his larger family right after his enthronement on December 27, 1603. Here, Gevherhan Sultan is listed as a recipient of a sable robe and recorded as the third female member of the dynasty after the retiring queen-mother, Safiye Sultan, and the new queen-mother, Handan Sultan, and before all other living sisters and daughters of Murad III and Mehmed III - a clear indication of her privileged position. Later, on February 6, 1604, she again appears in the register, this time as the only female family member apart from Handan Sultan to receive a fur-trimmed silk robe. TSMA, D. 2025, fols. $2 r$ and $4 \mathrm{v}$.

31 According to the Venetian bailo Ottaviano Bon, in-between his two sons' births, that is, between November 1604 and March 1605, Ahmed had his firstborn daughter. ASVe, SDC. Filza 61, fol. 19v (dated March 14, 1605). Although the names of two of Ahmed's (at least) five daughters, Gevherhan and Ayşe, are known, their exact birth dates remain unclear. 
when she became the concubine of the sixteen-year-old Prince Murad (III) since 1562, when he was the governor of Saruhan. ${ }^{32}$ Handan was probably at around the same age when she was presented to Prince Mehmed in 1582, thus we may assume that she was born in ca. 1570.

On January 14, 1584, Prince Mehmed, together with Handan and the rest of his harem, arrived in Manisa after a difficult journey that lasted a month under heavy winter conditions. ${ }^{33}$ A year later, in February 1585, the prince sent joyful news to Istanbul announcing that one of his concubines had recently given birth to a son. Alas, the official register which records this auspicious event does not mention the names of this newborn and his mother. ${ }^{34}$ But the son in question is almost certainly Selim, who has been conventionally accepted as Mehmed III's first-born prince. Since the Ottoman sultans' concubines and sons are poorly documented for this period, there is no way to be precise on either the total number or the birth order of children mothered by any given concubine. Nevertheless, we now know that Mehmed had at least two esteemed consorts in Manisa, namely, Halime and Handan, who gave birth to Prince Mahmud and Prince Ahmed, respectively. ${ }^{35}$ It is also certain that Mehmed had two daughters born at his princely court. ${ }^{36}$ In sum, when Mehmed III would return to Istanbul in late January 1595 to assume the throne upon the death of his father, he would have with him at least three sons (Selim, Mahmud and Ahmed) and two daughters. ${ }^{37}$

A few reliable contemporary sources, on the other hand, suggest that Mehmed III might have fathered more than these five children before his succession, and even that Handan was the mother of multiple sons and daughters, including Prince Selim. For instance, Lorenzo Bernado, who served as the Venetian bailo between April 1584 and December 1587, writes in his relazione of 1590 that Prince Mehmed "has two sons, Sultan Selim and Sultan [ ${ }^{\star \star \star *}$,

32 See Skilliter, “Three Letters from the Ottoman 'Sultana' Safiye to Queen Elizabeth I," 144. Skilliter also notes that Safiye was given to Prince Murad by his cousin Hümaşah Sultan, the wife of Ferhad Pasha, which is another point accentuating the similarity between these cases of Safiye and Handan.

33 Emecen, Imparatorluk Çağının Osmanlı Sultanları-II, 129. Emecen also notes that Mehmed's personal belongings and other items were shipped to İzmir in the company of his pages (içoğlanları), who then carried them to Manisa. As the only prince governing a province during the reign of his father Murad III, Prince Mehmed had around 2,000 people in his retinue together with an assigned income totaling 3,200,000 akçes (the equivalent of 40,000 Venetian gold ducats), an amount much larger than the official revenue of any vizier in the government. Kunt, "A Prince Goes Forth," 69.

34 TSMA, D. 34, fol. 88r. This treasury register, known as filori defteri, is now available in full transcription: Osman Yiğit, “Topkapı Sarayı Müzesi Arşivi 34 Numaralı Filori Defteri (Değerlendirme-Transkripsiyon)” (Unpublished MA thesis, Marmara Üniversitesi, 2018).

35 As Tezcan, "Searching from Osman," 329, n. 25, aptly observes, the birth order of Mahmud and Ahmed is actually not that certain. Conventional historiography holds that Mahmud was older than Ahmed by two years, thus born in 1588. However, according to the different accounts of the Venetian ambassadors cited by Tezcan, Ahmed might be older than his brother by one to three years. Here, I follow the established scholarship and consider Mahmud as the elder brother of Ahmed. As for Halime Sultan being the mother of Prince Mahmud, see below.

36 Tezcan, "Searching from Osman," 331, n. 37, notes that one of these daughters of Mehmed III was later married to Davud Pasha and the other one to Mirahor Mustafa Pasha in 1604. As for Şah Sultan, who was mentioned in an official document from January 1606 as the sister of Ahmed I, Tezcan thinks that she might be either Mehmed III's third daughter or the one married to Davud Pasha.

37 Emecen, Imparatorluk Çağının Osmanlı Sultanları-II, 129. 
and many daughters, from many of his slaves, whom he keeps in his service." ${ }^{38}$ Given that Bernado left the Ottoman capital before the births of Mahmud and Ahmed, the missing name in his report could well be Süleyman. Indeed, Leonardo Donà, the Venetian extraordinary ambassador who came to Istanbul in 1596 to congratulate Mehmed III on his enthronement, claims that the sultan had three sons ("Selim, Süleyman and Ahmed"), and two daughters, all by the same mother, that is, Handan. ${ }^{39}$ Similarly, Salomón Usque, an informant who wrote a detailed report in Italian for the English ambassador Edward Barton in February 1596 on the succession of Mehmed III, notes that the new sultan has either six or seven sons, but he gives only the names of eleven-year-old Selim as his eldest son and Süleyman as his secondborn..$^{40}$ Intriguingly enough, in conventional Ottoman historiography, Prince Süleyman is not cited among the sons of Mehmed III. ${ }^{41}$

As I had elsewhere noted in 2009, the Venetian ambassador Donà's indirect remarks about Handan Sultan being the mother of multiple sons and daughters could be a valid information, and as such would indicate that she was in effect a haseki of Mehmed III. ${ }^{42}$ However, since then, I have not personally come across any new or more concrete historical information to resolve this enigmatic problem regarding the actual number of Handan's children, let alone whether she had mothered a second son besides Prince Ahmed..$^{43}$ Be that as it may, let me emphasize that whereas Handan's haseki status is yet to be ascertained, there is no question as to that of Halime in that she was a favorite concubine of Mehmed III, who bore him at least two princes, Mahmud and Mustafa (the future Mustafa I, r. 1617-18; 1622-23), if not more. ${ }^{44}$

38 Eric Dursteler, In the Sultan's Realm: Two Venetian Ambassadorial Reports on the Early Modern Ottoman Empire (Toronto: Centre for Reformation and Renaissance Studies, 2018), 60. Here, the second prince's name is missing in the original report.

39 Federico Seneca, Il Doge Leonardo Donà: la sua vita e la sua preparazione politica prima del dogado (Padova: Editrice Antenore 1959) 286. Also noted in the same context by Tezcan, "Searching from Osman," 330, n. 29.

40 Jordi Canals, “Un informe otomano de Salomón Usque (1595)," Espacio, Tiempo y Forma, Serie IV, H.a Moderna 16 (2003), 153-181, at 169. Also see Tezcan, "Searching from Osman," 330, fn. 29 and Anthony D. Alderson, The Structure of the Ottoman Dynasty (Oxford: Oxford University Press 1956) 169, table XXXIII.

41 Tezcan, "Searching from Osman," 330, n. 29, also mentions the existence of a prince named Süleyman.

42 See Börekçi, "İnkırâzın Eşiğinde Bir Hanedan," 79-81.

43 To the best of my knowledge, no colleague has done so either. For instance, Feridun Emecen, one of the doyens of Ottoman history, writes that it is obvious that Handan gave Prince Mehmed multiple children in Manisa. However, he does not specify his sources or how he gleaned this idea. See Emecen, Imparatorluk Çağının Osmanlı Sultanları-II, 129.

44 According to the conventional historiography, Mustafa I was born in ca. 1591-92. İslâm Ansiklopedisi, s.v. "Mustafâ I," by M. Münir Aktepe. However, recent research has clearly shown that he must have been born in around 1601-02. See Tezcan, "The Debut of Kösem Sultan's Political Career," 353-354 and Börekçi, "Inkırâzın Eşiğinde Bir Hanedan," 71-74. Indeed, in his new biographical study of Mustafa I, Emecen accepts this later birthdate as the strongest possibility: Imparatorluk Çağının Osmanlı Sultanları-II, 187-188. Moreover, these cited authors underline another overlooked fact that Prince Mahmud and Mustafa I were full brothers, that is, they were the sons of Mehmed III and Halime Sultan. Yet, all this new historical information slowly replaces earlier assumptions, such as that Halime Sultan was executed in 1603 together with her son Prince Mahmud upon the suspicion of plotting for the throne. It is now firmly established that Halime was not executed, but instead sent to the Old Palace where she continued to nurture her little son Mustafa for several years, and ultimately became a regent queen-mother under her son's first sultanate. 
Identifying Halime's sons and haseki status is highly important for three main reasons. First of all, contrary to the established scholarly opinion, it shows that Mehmed III had actually followed the new policy of dynastic reproduction initiated by Süleyman I, that is, having more than one son by a single concubine. Secondly, it informs us about the dynamics and actors of an ever-deepening rivalry within the confines of the imperial harem under Mehmed III, and accordingly who Handan's chief rival was during the turbulent years of the late 1590s and the early 1600s. And finally, it helps us better explain not only the fierce competition that took place between Halime and Handan in the final years of Mehmed III's sultanate, but also why and how Halime lost her son Mahmud to a scheme, which was evidently designed by Safiye Sultan and supported by Handan. Hence, a detailed discussion of these related points is in order.

As Peirce explains, prior to Süleyman I, each of the sultan's concubines was allowed to produce only one son, although she could have daughters until the birth of a son curtailed her childbearing function. Sultan Süleyman broke this tradition, conventionally known as the "one mother-one son policy," not only by having multiple sons by his famous favorite concubine, Hurrem Sultan, but also by contracting a legal marriage with her. Each of Süleyman's immediate successors, Selim II (r. 1566-74) and Murad III, continued this new policy by favoring just one concubine, Nurbanu Sultan and Safiye Sultan, respectively. Thus, under these two sultans, the position of the favorite concubine gained a kind of institutional logic in that only the eldest sons of these hasekis (the future Murad III and Mehmed III) were sent to govern provinces and thus singled out among the other princes as the most likely candidates for the throne, which they indeed eventually took. ${ }^{45}$

Because none of Mehmed III's sons was assigned to a province during his father's or his own reign, scholars have assumed that Mehmed had no hasekis. Moreover, as I will explain below, Mehmed's government viziers were by mid-1602 pressuring him to designate an heir apparent. Yet, since Mahmud, by then the eldest living son of Mehmed III, was neither assigned to a province nor officially named crown prince, his mother's status as haseki was not fully established, in contrast to the cases of Nurbanu and Safiye Sultans in the past. In any case, the birth of Mustafa around 1601-1602 cemented Halime's status as the favorite concubine of Mehmed III.

Similarly, Ahmed I esteemed one of his concubines, Kösem Sultan, from 1605 onwards; by the end of his life, he had at least three daughters and four sons by her. Even, following the example of his role-model ancestor Süleyman I, Ahmed seems to have legally married Kösem in an uncertain year. ${ }^{46}$ Hence, the new Ottoman policy of dynastic reproduction initiated under Sultan Süleyman in the 1520s was well-established by the end of the sixteenth century and

45 Peirce, The Imperial Harem, 57-97.

46 According to the established scholarship, Kösem Sultan was the mother of Princes Murad, Kasım and Ibrahim. However, Tezcan, "The Debut of Kösem Sultan's Political Career," 350-351, convincingly demonstrates that she was also the mother of Prince Mehmed, the second son of Ahmed I, born in 1605. On the possible marriage of Ahmed I and Kösem Sultan, see Kumrular, Kösem Sultan, 110-112. 
continued in force until the end of Ahmed l's reign. Previously, the reign of Mehmed III was seen as a break with this pattern. ${ }^{47}$

For Mehmed III, the training of his sons for the sultanate, crucial as it was, was probably a secondary concern relative to their health and well-being. In an age in which infant and child mortality was quite high, having several healthy sons was a top priority for any sultan as the Ottoman dynastic succession had hitherto been from father to son in an unbroken male line. Against this backdrop, it is important to note that Mehmed IIl's family was much smaller and thus more fragile than those of previous sultans, notably that of his own father, Murad III, who fathered at least twenty sons and eleven daughters. ${ }^{48}$ Moreover, unlike his grandfather and his father, both of whom were succeeded by their first-born sons, Mehmed III had a tragic experience with his sons.

In 1597, his eldest son Prince Selim suddenly died at the age of thirteen, probably of plague..$^{49}$ If Handan Sultan was Selim's mother as suggested by Donà, she must have been truly devastated by his loss. In any event, with Selim's demise, the issue of dynastic continuity should have become a major concern for Mehmed III as he was likely left with only two small sons, ten-year-old Mahmud and seven-year-old Ahmed, at a time when, according to one rumor, the sultan had grown very fat and had health problems that curtailed his reproductive powers. ${ }^{50}$ Luckily, bad news about Mehmed's health soon proved wrong and he fathered another son from Halime, Prince Mustafa, born in Istanbul around 1601-02. In 1602, though, the sultan lost another son, Cihangir, about whom we know only that he was born in Istanbul and died at a very young age. ${ }^{51}$

47 Compare Peirce, The Imperial Harem, 104-105.

48 See Alderson, The Structure of the Ottoman Dynasty, tables XXXII and XXXIII; and Tezcan, "Searching for Osman," 327-328, n. 17 and 18.

49 According to Katib Çelebi, Prince Selim died on April 20, 1597: Zeynep Aycibin (ed.), Kâtib Çelebi, Fezleke, 2 vols. (Istanbul: Çamlıca, 2016), 1:287 [henceforth, Katib Çelebi, Fezleke]. The 1590s witnessed repeated outbreaks of plague in Istanbul, which reportedly took many lives at the Topkapı Palace and the Old Palace. See Nükhet Varlık, Plague and Empire in the Early Modern Mediterranean World: The Ottoman Experience, 1347-1600 (Cambridge: Cambridge University Press, 2015), 189-202. Selim seems to be a victim during one of these outbreaks. On the other hand, the report of the Venetian bailo Girolamo Cappello, dated 1600, points to a suspicion regarding Safiye Sultan's possible role in accelerating the death of Selim. According to Cappello, the prince was considered by many to be a good replacement for Mehmed III because of his vigor and because he was expected to diminish the power of Safiye Sultan. See Maria Pedani-Fabris (ed.), Relazioni di ambasciatori veneti al senato, vol. 14: Costantinopoli, Relazioni inedite (1512-1789) (Padua: Bottega d'Erasmo, 1996), 399-400. Also mentioned by Tezcan, "Searching for Osman," 329, n. 23, in the same context. Such allegations against Safiye Sultan sound like just rumors, hence probably had no foundations. However, they do point out to a growing dismay about Safiye's overwhelming influence in court politics by the turn of the seventeenth century, a point to which I will return.

50 Calendar of State Papers and Manuscripts, Relating to English Affairs, Existing in the Archives and Collections of Venice, and in Other Libraries of Northern Italy, 38 vols. (London: His Majesty's Stationery Office, 1864-1940), 9:269 [henceforth, CSP-Venetian]. It is certain that Mehmed III had grown very fat during these years. His contemporary images testify to this point. Compare, for instance, Pietro Bertelli, Vite degl'imperatori de Turchi, [NP] 1599, 54; Talîkizâde, Şehnâme-i Sultân-ı Selatîn-i Cihân, Topkapı Sarayı Müzesi Kütüphanesi (TSMK), MS Hazine 1609, fols. 68v-69r; and Ganîzâde Mehmed, Dîvân-ı Nâdirî, TSMK, MS Hazine 889, fols. 7r and 8v.

51 Hasan Bey-zâde Târîhi, ed. Nezihi Aykut, 3 vols. (Ankara: Türk Tarih Kurumu, 2004), 3:766 [henceforth, Hasan Bey-zâde Târîhi]; and Encyclopaedia of Islam, $2^{\text {nd }}$ edition, s.v. "Mehemmed III," by Susan Skilliter. 
Thus, barely a year before his death, Mehmed III had only three sons left: Mahmud, Ahmed and Mustafa, none of whom had been sent to govern a province or even circumcised. The eldest, Mahmud, was anxiously awaiting his provincial assignment. However, according to Agostino Nani, the Venetian bailo between 1600 and 1603, this had to wait for the ongoing Ottoman-Habsburg war in Hungary (known as the Long War of 1593-1606) and the incessant Celâli rebellions in Anatolia to come to an end. ${ }^{52}$ Under the exigencies of these wide-scale military engagements and social unrests, Sultan Mehmed did not really have much of a choice but to keep postponing his son's provincial assignment. But this situation triggered a fiercer rivalry among both his ruling elite and his royal women, which in turn altered the expected course of dynastic succession among his sons. At this point, we need to make an excursus and take a brief look at Mehmed III's crisis-ridden sultanate in order to better explain the impact of all these critical developments on Handan Sultan and her son Ahmed.

\section{A Sultan in Crisis}

In early 1596, a year after his enthronement, Mehmed III had decided to undertake an imperial campaign against the Habsburgs. The new sultan was actually convinced by his advisors and viziers that he had to lead his armies in person in order to present a powerful image of both himself and his empire, a task at which his father Murad III was thought to have failed, especially during the Ottomans' first lengthy engagement against the Safavids between 1578 and 1590. As a result of these prolonged battles on the eastern frontier, the later years of Murad's reign had witnessed financial instability and military problems, which provoked direct criticism of the increasingly sedentary and secluded style of his rule, and thus instigated a major military uprising in the capital. On April 2, 1589, for the first time in Ottoman history, the imperial cavalry soldiers (kapıkulu sipahileri) occupied the palace grounds to protest the payment of their salaries in debased coinage, then overtly rejected the sultan's authority by executing his beloved royal favorite, the governor-general of Rumeli Doğancı Mehmed Pasha, whom Murad had authorized to handle certain imperial affairs, including salary payments and currency devaluation. ${ }^{53}$

The ramifications of this so-called "Governor-General Incident" (Beylerbeyi Vak'ası) were so momentous in contemporary court politics that Murad III countered his unruly soldiers and their supporters among the viziers and the scholar-jurists (ulema) by immediately removing the entire higher echelon of his government; he even thought of running the empire without a grand vizier, but this was simply an impossible idea to realize given the well-established

52 Luigi Firpo (ed.), Relazioni di ambasciatori veneti al senato, tratte dalle migliori edizioni disponibili e ordinate cronologicamente, vol. 13: Costantinopoli (1590-1793) (Torino: Bottega d'Erasmo, 1984), 399.

53 The soldiers also murdered the chief treasurer, Mahmud Efendi. For the unfolding of the incident, see Tarih-i Selânikî, 1:209-213. 
sixteenth-century Ottoman administrative practices. ${ }^{54}$ Overall, as Christine Woodhead aptly observes, when Mehmed III took the throne six years later, he knew that he had to make "a break with his father's practices, not only by clearing the palace of Murad's large domestic household and the dwarfs and mutes who had entertained him, but also by acquiescing in personal leadership of the 1596 Hungarian campaign, an action intended to signal the renewal of direct imperial authority." 55

At the outset, Sultan Mehmed's sole aim was to capture the fortress of Eger, situated between Austria and Transylvania, which, together with Moldavia and Wallachia, was under Habsburg suzerainty. The fortress fell to the Ottomans on October 12, 1596, after a siege of three weeks. ${ }^{56}$ Still, in order to secure Eger and its surroundings, the Ottomans had to stave off the Habsburg imperial army under the command of Archduke Maximilian, who had been sent to relieve the fortress. The climactic battle took place in the nearby plain of Mezőkeresztes (Haçova) on October 25-26, and the decisive moment came on the second day as the Habsburgs, thanks to their numerical superiority and better artillery and tactical organization, crushed the Ottoman forces and penetrated deep into the center of their camp. Seeking booty, the Habsburg soldiers started to plunder the Ottoman tents, but the fleeing Ottoman cavalry and infantry suddenly turned back and caught them off guard. ${ }^{57}$ The result was a devastating defeat for the Habsburgs and a decisive, if last-minute, victory for the Ottomans. Mehmed III now earned the honorific title of warrior sultan (gâzî sultân) and entered his capital in an elaborate ceremony celebrating his and his imperial army's achievements. ${ }^{58}$

But these sounding Ottoman victories neither brought an end to the war, nor helped Mehmed III in the way he aspired. Peace overtures remained unfulfilled as border fortresses

54 Tezcan, The Second Ottoman Empire, 56. For a detailed discussion of this rebellion and its historical significance, see Börekçi, "Factions and Favorites," 172-195. Also see Cemal Kafadar, "Prelude to Ottoman Decline Consciousness: Monetary Turbulence at the end of the Sixteenth Century and the Intellectual Response," Osmanlı Araştırmaları 51 (2018), 265-295.

55 Christine Woodhead, "Murad III and the Historians: Representations of Ottoman Imperial Authority in Late $16^{\text {th }}$ century Historiography," in Legitimizing the Order: The Ottoman Rhetoric of State Power, ed. Hakan T. Karateke and Maurius Reinkowski (Leiden: Brill, 2005) 85-98, at 97-98. In her article, Woodhead provides an excellent discussion of the negative representations of Murad III's reign and efforts by contemporary royal historians to counter the criticisms of his style of rule.

56 See Sándor László Tóth, A mezőkeresztesi csata és a tizenöt éves háború (Szeged: Belvedere, 2000) 186-199, for a detailed analysis of the fall of Eger.

57 For the details and different scholarly interpretations of this climactic battle, compare ibid., 223-261 and Feridun Emecen, "Sonucu Olmayan Büyük Zafer: Haçovası Meydan Savaşı," in Savaşın Sultanları: Osmanlı Padişahlarının Meydan Muharebeleri, ed. Coşkun Yılmaz, 2 vols. (Istanbul: Bilge Yayım Habercilik, 2018), 2:66-145.

58 The Ottoman successes at Eger and Mezőkeresztes, as well as Mehmed III's entry into the capital, are covered in several contemporary victory missives (feth-nâmes), narratives and images. Inter alia, see Talîkīzâde, Şehnâme-i Sultân-ı Selâtîn-i Cihân; Ganîzâde Mehmed, Dîvân-ı Nâdirî, TSMK, MS H. 889, fols. 5a-7a; Konya Bölge Yazma Eserler Kütüphanesi, MS 3630 (a copy of Gazanfer Agha's letter on the Ottoman victories), published by Hasan Ali Esir, "Eğri Kalesi'nin Fethi ve Haçova Meydan Savaşı'ıı Anlatan Fetih-name Türünde Bir Mektup," Çukurova Üniversitesi Sosyal Bilimler Enstitüsü Dergisi 17/2 (2008), 177-190; and Günhan Börekçi, Macaristan'da Bir Osmanlı Padişahı: Sultan III. Mehmed'in Eğri Seferi Rûznâmesi (1596) (İstanbul: Metamorfoz Yayınları, 2016). 
continued to change hands, and by the early 1600s, the war on the Ottoman-Habsburg frontier was more or less static, logistically wearying and financially exhausting for both sides.$^{59}$ For the Ottoman soldiers and commanders, however, the annual campaigns were turning into costly and hazardous adventures as they often had to fight in unfavorable weather without sufficient provisions or money. ${ }^{60}$ Most importantly, the financial burden of the Long War, which the Ottomans fought while simultaneously contending with the aforementioned Celâlis, was so heavy for Mehmed III and his government that they had to impose new taxes on the peasant population and expand the system of tax-farming as well as other revenue-raising methods in order to control the budget deficits. ${ }^{61}$

Under these circumstances, disgruntled soldiers, particularly the imperial cavalry troops began raising their voices, both during and after the campaigns, against the mismanagement of their military and financial affairs by members of the government and the court. Soon, their discontent turned into open rebellion which targeted Mehmed III and his court in general, and more particularly the sultan's mother, Safiye Sultan, and her court faction, and above all the

59 A statistical study by the Hungarian historian László Nagy reveals that sixty-three of the eighty-three engagements between the two rivals during the Long War ended with Ottoman defeats - though most of these were smallscale skirmishes and did not produce "decisive" results in terms of uprooting the Ottoman presence in Hungary. Cited in Tibor Szalontay, "The Art of War during the Ottoman-Habsburg Long War (1593-1606) according to Narrative Sources" (PhD diss., University of Toronto 2004), 150, n. 39.

60 The chronicle of Abdülkadir Efendi, who served in the artillery corps during the Long War, provides vivid accounts of Ottoman soldiers' fighting experience; see Topçular Kâtibi ‘Abdülkādir (Kadrî) Efendi Tarihi, ed. Ziya Yılmazer, 2 vols. (Ankara: Türk Tarih Kurumu, 2003). See esp. 1:171, 201, 205-207, 218-223, 260, 265-269, 300-301, 319-320, 330, 341, 347 and 370, for freezing winter days, floods and rainstorms, famine and epidemics, and logistical problems.

61 On the financial burden and devastation of the Long War in the Hungarian provinces of the empire, see Caroline Finkel, The Administration of Warfare: The Ottoman Military Campaigns in Hungary, 1593-1606 (Vienna: Verband der wissenschaftlichen Gesellschaften Österreichs, 1988) and Klára Hegyi, "The Financial Position of the Vilayets in Hungary in the 16th-17th Centuries," Acta Orientalia Academiae Scientiarum Hungaricae 61/1-2 (2008), 77-85. For a comparative table of Ottoman budget deficits during this period, see Erol Özvar, "Osmanlı Bütçe Harcamaları," in Osmanlı Maliyesi: Kurumlar ve Bütçeler, ed. Mehmet Genç and Erol Özvar, 2 vols. (İstanbul: Osmanlı Bankası Arşiv ve Araştırma Merkezi, 2007), 1:197-238. For the changes in Ottoman tax-farming system and the introduction of new tools for revenue-raising during this period, see Linda Darling, RevenueRaising and Legitimacy: Tax Collection and Finance Administration in the Ottoman Empire, 1560-1660 (Leiden: Brill, 1996) and Pál Fodor, The Business of State: Ottoman Finance Administration and Ruling Elite in Transition (1580s-1615) (Berlin: Klaus Schwarz, 2018). 
powerful royal favorite, Gazanfer Agha, the chief eunuch of the palace (kapu ağası). ${ }^{62}$ These military revolts, which took place in the Ottoman capital in 1600, 1601 and 1603, and found critical support from various highest-ranking members of the ulema, reveal the complicated dynamics of practical politics while pointing up the intensified factionalism within the imperial court and harem. ${ }^{63}$ In this particular context, the rebellion of 1603 was especially a momentous event in that it soon defined the future of Mehmed III's sons as well as of their mothers.

It was the first week of January 1603 when this third and most violent uprising against Mehmed III broke out, once again among soldiers who had recently returned from an antiHabsburg campaign. When the cavalry troops reached the capital after a long and miserable journey, they quickly joined forces with the Janissaries, who were likewise furious about the suffering, humiliation and casualties of the campaign. ${ }^{64}$ On January 4 , the imperial sipahis and Janissaries jointly rebelled and even took indirect control of the government, forcing the sultan to replace a number of key officials, including Yemişci Hasan Pasha, the grand vizier and the commander-in-chief of the campaign, and to reinstate Sunullah Efendi as mufti, who was deposed for being one of the ringleaders of the second rebellion in $1601 .{ }^{65}$

Given that the sipahis, the Janissaries and the newly appointed top-ranking ulema formed such a united front against the sultan's court and particularly Safiye's faction, and that they again threatened the sultan with deposition like they had done in 1601, Mehmed III had no option but to confront his unruly soldiers in person. Two days later, he met with the leaders of the outraged sipahis who demanded the executions of Gazanfer Agha; Osman Agha, the chief eunuch of the imperial harem (dârüssaâde ağası); ${ }^{66}$ and Saatçi Hasan Pasha, who was just dismissed from the deputy grand vizierate. They held these three men and their cronies responsible for corrupting military affairs, intervening in the government decision-making

62 Gazanfer Agha had been a very powerful actor in court politics since the early years of Murad III's reign. Most importantly, he was one of the royal favorites created by Sultan Murad, in which capacity, over the years, he assembled a large network of clients and protégés composed of his own family members, merchants, court officials, government ministers, artists and intellectuals. See Cornell H. Fleischer, Bureaucrat and Intellectual in the Ottoman Empire: The Historian Mustafa Âli (1541-1600) (Princeton: Princeton University Press, 1986), 72, 110-114, 125-126, 169-171, and passim; Emine Fetvacı, Picturing History at the Ottoman Court (Bloomington: Indiana University Press, 2013), 239-265; Pedani, “Safiye's Household;" Eric Dursteler, “Fatima Hatun née Beatrice Michiel: Renegade Women in the Early Modern Mediterranean," The Medieval History Journal 12/2 (2009), 355-382; Levent Kaya Ocakaçan, “The Changing Dynamics of the Ottoman Patronage Networks (Late $16^{\text {th }}$ and Early $17^{\text {th }}$ Centuries)," Archivum Ottomanicum 34 (2017), 9-18 and Jane Hathaway, Chief Eunuch of the Ottoman Harem: From African Slave to Power-Broker (Cambridge: Cambridge University Press 2018) 52-54, 59-69, 80-87 and passim.

63 For a detailed discussion of these rebellions, see Börekçi, "Factions and Favorites," 48-63.

64 Hasan Bey-zâde Târîhi, 3:690; and Mehmed bin Mehmed, Nuhbetü't-tevârîh, in Sağırlı (ed.), "Mehmed b. Mehmed Er-Rumî (Edirneli)'nin Nuhbetü’t-tevârîh ve'l-ahbâr'ı ile Târîh-i Âl-i Osmân'ının Metni ve Tahlilleri," p. 587 [hereafter Mehmed bin Mehmed, Nuhbe].

65 As a result of the sipahi rebellion in March 1601, Sunullah Efendi had been replaced with Hocazade Mehmed Efendi on August 2, 1601. For Sunullah Efendi and his political career, see Mehmet İpşirli, "Şeyhülislâm Sun'ullah Efendi," İstanbul Üniversitesi Tarih Enstitüsü Dergisi 13 (1983-1987), 209-256.

66 For Osman Agha and his political influence, see Hathaway, Chief Eunuch of the Ottoman Harem, 83-87. 
process, and downplaying the threat posed by the Celâli rebels sweeping through Anatolia, in short, for the empire-wide disorder and devastation. ${ }^{67}$

To counter these accusations, Saatçi Hasan Pasha produced letters from the queenmother and the two chief eunuchs instructing him not to reveal to the sultan any bad news related to the military campaigns. Mehmed III therefore pardoned him. The Janissaries then interceded for their former agha, Tırnakçı Hasan Pasha, who was likewise spared. Even Safiye Sultan, now that her faction was incapacitated, was allowed to remain in Topkapı Palace. Gazanfer and Osman Aghas were not so lucky, however: they were taken from the inner court and decapitated before the sultan's eyes on January 6, 1603.68

Accounts vary as to whether the soldiers seriously considered deposing the sultan. According to the English ambassador Henry Lello, they threatened to replace him with one of his sons, probably Prince Mahmud. ${ }^{69}$ A contemporary chronicler Hasan Beyzade, however, repeatedly claims that the sipahis attempted to put mufti, Sunullah Efendi, on the throne on the grounds that the leader of the Muslim community should be chosen for his virtues. ${ }^{70}$ The idea of replacing the sultan not with another member of the Ottoman dynasty but with a member of the ulema had never been put forward in the three centuries of the Ottoman Empire's existence! ${ }^{71}$

Besides shaking the sultan's throne and creating such a deep turbulence in dynastic and court politics, the 1603 rebellion also affected Mehmed's psychology. The idea of being dethroned now made him all the more suspicious about the aspirations and actions of his sons and their mothers. Indeed, only six months after this rebellion, he ordered the execution

67 Hasan Bey-zâde Târîhi, 3:690-691; Katip Çelebi, Fezleke, 246; and İbrahim Peçevi, Tarîh-i Peçevî, TSMK, MS Bağdad 2006, fol. 279r [henceforth, Tarîh-i Peçevî].

68 Orhan Burian (ed.), The Report of Lello: Third English Ambassador to the Sublime Porte (Ankara: Türk Tarih Kurumu, 1952), 11-12 [henceforth The Report of Lello].

69 Ibid.

70 Hasan Bey-zâde Târîhi, 3:692, 736: "Az kaldı ki, hal'-ı saltanat olayazdı. 'Hılâfet, efdaliyyet iledür' diyü, Mevlânâ Sun “ullâh'ı zümre-i sipâh serîr-i saltanata iclâs ideyazmışlar." "Hasan Paşa, pâdişâh-ı memleket-güşâya zümre-i sipâh müftî-i sâbık Sun 'ullâh'ı serîr-i hilâfete iclâs kasdın eyledüklerin bildürüp [...]." Also noted by Tezcan, "Searching for Osman," 127 and Feridun Emecen, "Osmanlı Hanedanına Alternatif Arayıșlar Üzerine Bazı Örnekler ve Mülahazalar," in idem, Osmanlı Klasik Çağında Hanedan, Devlet ve Toplum (İstanbul: Timaş Yayınları, 2011), 37-60 [at 45-46].

71 The implications of this alleged attempt to replace Mehmed III with the mufti are thus highly significant. First and foremost, it points to the criticism directed against the sedentary style of rule that the Ottoman sultans had adopted under Murad III, that is, against the sultan's utilization of royal favorites and their court factions instead of being directly involved in the business of rule. Secondly, it suggests that the Ottoman sultan was no longer considered irreplaceable as a monarch and even that the Ottoman dynasty was no longer sacrosanct. Indeed, from this moment onwards, the search for an alternative to the rule of the House of Osman would resurface more often, particularly during similar large-scale military rebellions, such as in 1622 and 1703 . Thirdly, it marks the beginnings of the so-called "kul problem" that would plague the Ottoman capital and provinces, particularly Egypt, in the seventeenth century, as a result of which Ottoman rulers would face deposition and even execution, as in the cases of Osman II and Sultan Ibrahim. Last but not least, it shows the growing power and prestige of the mufti within the Ottoman body politic. 
of Prince Mahmud on the suspicion that he was plotting to seize the throne. This act not only paved the way for Prince Ahmed to succeed his father, and accordingly Handan Sultan to replace Safiye Sultan as queen-mother, but also suddenly brought the male line of the Ottoman dynasty to the brink of extinction.

\section{A Turning Point}

According to contemporary sources, the tragic end of Mahmud was triggered when Halime Sultan asked a Sufi sheikh to tell her son's fortune. The sheikh's letter of reply predicted that Mahmud would succeed to the throne within six months, after unpleasant things happened to his father. However, the letter was intercepted by the chief eunuch of the imperial harem, Abdürrezzak Agha, who then gave it to Mehmed III and his mother Safiye Sultan instead of delivering it to the prince's mother. ${ }^{72}$

For a sultan who had faced three military revolts and been threatened with deposition twice in the past three years, such a letter would no doubt have raised suspicions of treason, particularly at a time when Mahmud was said "[...] to grieve and murmur to see how his father was altogether led by the old Sultana his grandmother and the state went to ruin."73 Meanwhile, the Venetian bailo Contarini heard rumors about a conspiracy to poison Mehmed III in order to "bring the Prince [Mahmud] to the command of the empire."74 In the end, after a brief period of imprisonment, interrogation and even torture to make him confess, Prince Mahmud was strangled for plotting to seize the throne. ${ }^{75}$ As for his mother Halime, she was not executed as conventional historiography still holds. Instead, she was exiled to the Old Palace so as to keep nurturing her little Mustafa. ${ }^{76}$

The execution of Prince Mahmud was surely a much more complex event in that there were other historical factors and political actors involved in its unfolding. As Peirce shows, a series of institutional changes took place in the Ottoman dynastic establishment between the reigns of Süleyman I and Murad III, as a result of which the queen-mother became the head of the imperial harem whereas the favorite concubine of the sultan had to compete with her "for influence over the sultan and over factions in government." ${ }^{\prime \prime}$ "In the seventeenth century," Peirce continues, "when princes and their mothers were resident in the imperial palace rather than

72 Hasan Bey-zâde Târîhi, 3:765. One of Contarini's dispatches reveals the timing of these events. ASVe, SDC, filza 57 , fols. 209v-210r (dated May 13, 1603).

73 The Report of Lello, 14 [I have modernized the spelling].

74 ASVe, SDC, filza 57, fol. 314 r (dated June 14, 1603).

75 Mehmed bin Mehmed, Nuhbe, 595; ibrahim Peçevi, Tarîh-i Peçevî, fols. 288r-289r; and İsmail Hakkı Uzunçarşıll, “Üçüncü Mehmed'in Oğlu Şehzade Mahmud'un Ölümü," Belleten 94 (1960), 263-267. Contarini notes that four mutes executed Prince Mahmud in a harem room while Mehmed III waited outside. After his order was carried out, the sultan entered the room to make sure that the prince was dead. Ahmed should have been present in his own harem room at the time. ASVe, SDC, filza 57, fol. 313 r (dated June 14, 1603).

76 On the survival of Halime Sultan and her banishment to the Old Palace, see Börekçi, "Factions and Favorites," 67-68.

77 Peirce, The Imperial Harem, 91. 
in a distant province, they needed to be extremely discreet. They were under the watchful eye not only of the sultan, but of the valide sultan and of mothers and supporters of rival princes. The valide sultan was the most formidable challenge to a prince's mother because she was equally intent on protecting the interests of her own son, the sultan." According to Peirce, this type of clash between two generations of mothers in the royal family is best illustrated in the affair of Prince Mahmud, "whose mother was not sufficiently circumspect in her efforts to bolster the prince's candidacy."78

It was indeed a clash between Safiye Sultan and Halime that eventually led to execution of Mahmud, but this conflict also drew in Handan Sultan, a point often overlooked. Furthermore, it occurred in the absence of Gazanfer Agha, who had been so central to Safiye Sultan's overwhelming control of imperial and dynastic politics. The conflict among the three royal women was not unrelated to the soldiery revolts mentioned earlier. A year before Mahmud's tragic end, a heated discussion took place among the viziers of the imperial council, apparently as a result of the sipahi rebellion in 1601, as to which of the sultan's sons should be designated heir to the throne. According to a Venetian intelligence report, which was sent to the court of Queen Elizabeth I in late July 1602, the viziers were divided into two groups: one supporting Prince Mahmud since he was the eldest prince, the other favoring his younger half-brother Ahmed in the belief that Mahmud was unable to father children. ${ }^{79}$ No doubt the imperial Janissaries and sipahis took sides in this debate, as well.

Against this backdrop, Halime Sultan tried to persuade her husband to single out their eldest son Mahmud as his heir and send him to a province, just as Mahmud himself had wished. Clearly, the haseki and her son had their supporters among the viziers and soldiers. Meanwhile, Handan Sultan, as the mother of the only other viable candidate for the throne, was alarmed by Halime's actions and decided to side with Safiye Sultan in order to protect her own son, Prince Ahmed, if not to promote him for the throne instead of his half-brother. Handan may well have been the source of the rumor about Prince Mahmud's infertility, since she had every reason to undermine him before the sultan decided on a successor. Mehmed III's response to these machinations remains unclear.

While this succession debate dragged on, the 1603 rebellion broke out. In the course of the tumult, Safiye Sultan reportedly became more and more suspicious of Halime Sultan and Prince Mahmud. According to another rumor circulating in the capital, if their conspiracy to assassinate the sultan failed, Mahmud would be secretly taken to a province, where he could easily gather an army and fight for the throne ${ }^{80}$ Indeed, the English ambassador Lello and

78 Ibid., 231-232, citing the incident of the Sufi sheikh's letter and the rumors of a plot against Mehmed III, and quoting the report of the English ambassador Lello.

79 Edward Salisbury (ed.), Calendar of the Manuscripts of the Most Hon. the Marquis of Salisbury, Preserved at Hatfield House, Hertfordshire, 26 vols. (London: His Majesty's Stationery Office, 1923), 14:226-227 (dated July 26, 1602).

80 ASVe, SDC, filza 57, fols. 313r-v (dated June 14, 1603). 
the Venetian bailo Contarini both indicate that Safiye Sultan was the mastermind behind the execution of Prince Mahmud, a solution which she apparently put forward in order not only to relieve the sultan of deposition anxiety but also to eliminate Halime Sultan, of whom she was reportedly "very jealous" (read threatened). According to Contarini, the queen-mother had the open support of Handan Sultan in this scheme. ${ }^{81}$

In the end, with Mahmud's demise, Ahmed attained the status of heir apparent as he was now the sole viable candidate for the throne. Soon after Mahmud's execution, Safiye Sultan took the prince with her to the Golden Horn to watch the state ceremony organized for the first sailing of the new galley constructed by Grand Admiral Cigalazade Sinan Pasha. Hence, contrary to the established scholarship, by exposing Ahmed in such an occasion "to the sight of everyone because of the loss of the other son," Safiye Sultan was officially declaring him the crown prince. ${ }^{82}$ In a similar vein, upon Mufti Ebülmeyâmin Mustafa Efendi's advice, Mehmed III ordered proper arrangements to be made, "because he wanted his son, the Prince [Ahmed], to be always with him in the mosque and other public places where it would be necessary for him to appear." ${ }^{83}$

Even though Handan would not accompany her son in these occasions (as the Ottoman custom forbade sultan's concubines to be seen in public), she surely enjoyed her new status as the mother of the heir apparent. And that status lasted a little over six months. On the night of December 20,1603, Sultan Mehmed suddenly died in his bedchambers at the age of thirty-seven, seemingly due to a heart attack. ${ }^{84}$ The following morning, an impromptu ceremony was organized at Topkapı Palace to announce the enthronement of Ahmed I. Now, with her teenage, barely pubescent, uncircumcised, childless and inexperienced son sitting on the Ottoman throne, a whole new and more challenging episode opened up in Handan's life.

\section{A Queen-mother at Work}

Ahmed l's enthronement was truly an unusual event in many respects and as such created a series of dynastic precedents and pressing problems, which demanded Handan Sultan's direct and careful handling as the new matriarch of the House of Osman. First and foremost, upon his father's unexpected death, Ahmed had to take the throne at all costs since the only other surviving male member of the dynasty, his half-brother Mustafa, was barely four years old and thus too young to be considered a viable alternative. Hence, Ahmed's enthronement stemmed from the need to retain the traditional pattern of father-to-son sequential succession

81 For details, see Börekçi, "Inkırâzın Eşiğinde Bir Hanedan," 77 and 82-85.

82 ASVe, SDC, filza 57, fols. 356v-357r (dated June 28, 1603).

83 Ibid., fol. 358v. This order of Mehmed III can also be interpreted as a sign of caution against a possible dethronement attempt by the imperial cavalry soldiers and their supporters.

84 Shortly after Mehmed III's death, the royal doctors had second thoughts as to why the sultan had suddenly passed away. According to the Venetian bailo's intelligence, some doctors believed he died from the plague, but for most, the cause was a stroke: ASVe, SDC, filza 58, fol. $254 r$ (dated January 3, 1604). Also see a brief excerpt from this dispatch in CSP-Venetian, 10:127. 
while sustaining hope that the Ottoman dynasty could survive. However, being the first sultan to assume the throne childless at a time when there was no other adult male in the dynastic family, Ahmed had to quickly prove his biological ability to father a child and, most critically, had to have at least one healthy son in order to secure the unbroken 300 -year-old male line of dynastic succession. ${ }^{85}$

This extraordinary situation helps to explain why Ahmed did not apply the Ottoman custom of fratricide (kardeş katli), which allowed a new sultan to order the execution of all his living brothers. ${ }^{86}$ Unlike his grandfather Murad III and his father Mehmed III, who had been free to engage in fratricide immediately upon their enthronements since they each had several sons, Ahmed had to keep his half-brother alive so as not to risk the extinction of the dynasty. ${ }^{87}$ Moreover, little Mustafa was apparently not considered a potential threat to Ahmed's sovereign power, and the young sultan was accordingly advised by his regents to take any action against him. The observations of Francesco Contarini, the Venetian bailo resident in Istanbul at the time, are very telling in these respects:

He has not otherwise had to have his only brother put to death, because the Sultan has said that he wishes to keep and cherish him like a son, but one must suppose that, for that purpose, he might have been persuaded by those who advise him. Since he does not yet have any children, they have considered it opportune for the continuation of the House of Osman not to rest solely in him in the face of such danger [i.e., of accidental death], especially since his brother is about four years old, so that little is to be feared from him, but it is best to wait some length of time for this eventuality, until the Sultan can secure his posterity. ${ }^{88}$

85 The Ottoman dynasty had never faced such a problem of continuity because of an under-aged sultan succeeding to the throne. The closest example is that of Mehmed II (r. 1444-46; 1451-81), who was similarly twelve years old and childless in 1444, when his father Murad II (r. 1421-44; 1446-51) abdicated in his favor. Though Mehmed II had no known living or mature brothers during his short first reign, his father was alive and in his early forties, still capable of fathering a child. Thus, Mehmed's childlessness did not create a potential dynastic crisis as in Ahmed's case. For details, see Alderson, The Structure of the Ottoman Dynasty, tables I-XXVII.

86 On the Ottoman custom of fratricide, see Halil İnalcık, "Osmanlılarda Saltanat Veraset Usulü ve Türk Hakimiyet Telâkkisiyle ilgisi," Ankara Üniversitesi Siyasal Bilgiler Fakültesi Dergisi 14 (1959), 69-94; Joseph Fletcher, "TurcoMongolian Monarchic Tradition in the Ottoman Empire," Harvard Ukrainian Studies 3-4 (1979-1980), 236-251; and Peirce, The Imperial Harem, 20-25, 79-90, 101-103 and passim. This custom was legally justified by a law (kānûn) attributed to Mehmed II. For the text of the law and a discussion of its authenticity, see Abdülkadir Özcan (ed.), Kānûnnâme-i Âl-i Osman: Tahlil ve Karşılaştırmalı Metin (İstanbul: Kitabevi, 2003).

87 As is known, Murad III had five brothers and Mehmed III nineteen brothers killed at their successions. Ahmed I would never apply this custom, a decision which would eventually change the pattern of Ottoman dynastic succession: when Ahmed died in 1617, he left several sons, the eldest being thirteen-year-old Osman, who, along with Ahmed's brother Mustafa, was eligible to rule. This was a situation unprecedented in Ottoman history. A court faction then secured the enthronement of Mustafa instead of Osman, thus further solidifying the end of royal fratricide and confirming a new principle of seniority in succession.

88 ASVe, SDC, filza 58, fol. 255v (dated January 3, 1604) [emphases are mine]. Ten months later, Contarini personally observed Prince Mustafa as a little child traveling in the company of the queen-mother. He observed that the prince "was nurtured like an innocent little sheep [who] must soon go to the butcher's, and he showed the most handsome countenance." ASVe, SDC, filza 60, fol. $11 \mathrm{r}$ (dated September 18, 1604). Here, the bailo is undoubtedly referring to Mustafa's young age once again, while voicing the public expectation of imminent fratricide. 
By the time of Ahmed's enthronement, then, the reproduction of the dynasty rested solely on the health and virility of a pubescent sultan. But contemporary evidence suggests that Ahmed was in poor health at the time of his enthronement and may have been unwell for some time. For instance, Contarini reported that the new sultan was "thirteen years old, of white complexion and displayed a weak constitution, as was also understood to be true." 89 The House of Osman had never before faced such a serious threat of genealogical extinction.

In this context, Ahmed l's enthronement created another dynastic precedent: he became the first Ottoman ruler to be circumcised after assuming the sultanate. His circumcision took place more than a month after his accession, on Friday, January 23, 1604. ${ }^{90}$ However, no direct evidence has thus far surfaced as to whether this royal event was officially announced in advance or whether there was any plan to celebrate it with a public festival similar to the one organized for his father's circumcision in 1582. ${ }^{11}$ Such a public spectacle was probably deemed unsuitable, if not financially impossible, at a time when the ramifications of the dynastic, military and political crises that had erupted at the end of Mehmed III's reign were still fresh in the public consciousness. ${ }^{92}$

In any case, it is reported that a royal household party was instead held inside the palace to mark this auspicious event. ${ }^{93}$ We can easily assume that Handan Sultan was personally involved in the planning of this party and that she hosted a number of guests, including her former owner, Gevherhan Sultan, who was now the second highest-ranking royal woman in the imperial harem after the queen-mother. ${ }^{94}$ As part of the planned activities, the young sultan and the guests were entertained with some staged plays. Interestingly, one of the themes chosen for these performances was designed to boost Ahmed's confidence and to emphasize that despite his youthfulness and inexperience, he would be a great warrior ruler of an empire which had been at war with the Habsburgs since the early 1590s:

89 ASVe, SDC, filza 58, fols. 231r-231v (dated December 21, 1603).

90 Mehmed bin Mehmed, Nuhbe, p. 617 and Mustafâ Sâfî, Zübdetü't-tevârîh, (ed.) İbrahim Hakkı Çuhadar, 2 vols. (Ankara: Türk Tarih Kurumu, 2003), 1:19 [henceforth, Sâfî, Zübdetü't-tevârîh]. The Venetian bailo's dispatch, ASVe, SDC, filza 58, fol. 336r (dated February 3, 1604), confirms that Ahmed's circumcision took place on a Friday.

91 For instance, the dispatches of the Venetian bailo Contarini, whose intelligence network was designed exclusively to collect information about the events taking place at the Ottoman court, do not contain any information pertaining to these events.

92 I would also speculate that even if there were plans to hold public celebrations of Ahmed's circumcision, they were probably cancelled due to the unusually cold winter of 1603. Climatological analyses confirm that winters in the northwestern Anatolia in the early 1600s were extremely cold. For instance, the winter of 1607-08 was probably the driest and certainly one of the coldest in the last millennium. For details, see Jürg Luterbacher and Elena Xoplaki, "500-Year Winter Temperature and Precipitation Variability over the Mediterranean Area and Its Connection to the Large-Scale Atmospheric Circulation," in Mediterranean Climate: Variability and Trends, ed. Hans-Jürgen Bolle (Berlin: Springer Verlag, 2003), 133-153.

93 Sâfî, Zübdetü't-tevârîh, 1:19-21.

94 See fn. 29 above. 
On the occasion of the circumcision, many celebrations and parties were held by the pages inside the palace with fireworks, bell-tolling, and other things; in particular, they represented the acquisition of a city, giving it the name of Vienna, first sending the king of the Tartars to despoil the surrounding [territory] and similar things, until at the end, the Sultan entered [Vienna] in victory and triumph. ${ }^{95}$

In the meantime, according to Contarini, some concubines were already chosen and prepared for Ahmed by his mother and aunts so that he could sleep with them as soon as possible. ${ }^{96}$ Given that Ahmed's first child, Prince Osman, was born on November 3, 1604, he must have indeed slept with his concubine, Mahfiruz, right after he recovered from his circumcision. At that time, the birth of a prince naturally created much joy and excitement in the court and capital as it proved that the young sultan was able to father children. Ahmed named his son Osman, after eponymous founder of the Ottoman dynasty, and ordered public celebrations for seven days and nights in all corners of the empire. The birth of Prince Osman was such an important event that Ahmed appeared on the throne the next day so that the members of his government and other grandees of the court could kiss his hands and congratulate him, just as they would on a religious holiday. The birth of the prince was also announced to the representatives of foreign states resident in the capital. ${ }^{97}$

Another important dynastic precedent that marked the early reign of Ahmed I was that, since he was never sent out to a province, he was the first Ottoman prince to take the throne without a household of his own that could provide a pool of loyal servants to replace the existing court and government functionaries. Instead, he inherited his father's household and government as they were. As a result, Ahmed found himself with a royal court divided by intense factionalism, as well as an empire engaged in wars with the Habsburgs in the west and (since early 1603) with the Safavids in the east while preoccupied and stretched thin by military and peasant rebellions in its central lands. The young sultan thus needed guidance in ruling and in running his court. The Venetian bailo Contarini immediately informed his Senate exactly of the problems confronting the new teenage sultan:

95 ASVe, SDC, filza 58, fol. 336v (dated February 3, 1604). Particularly since the reign of Süleyman I, the Ottomans had had an imperial ambition to conquer Vienna, to which they occasionally referred as the Red (or Golden) Apple (KIzIl Elma). Thus, while this particular play staged at Ahmed's circumcision party can be read within the context of contemporary political events, it can also be taken as an indication of Ottomans' never-ending expectation of a warrior sultan who could continue the imperial territorial expansion. As will be discussed below, Ahmed would respond to such expectations by attempting to personally lead a military campaign, as well as by emulating the ruling style of his great-grandfather. For a discussion of the centrality of Vienna/Red Apple in early modern Ottoman imperial imagination, see Pál Fodor, "The View of the Turk in Hungary: The Apocalyptic Tradition and the Legend of the Red Apple in Ottoman-Hungarian Context," in Les traditions apocalyptiques au tournant de la chute de Constantinople: Actes de la Table ronde d'Istanbul (13-14 avril 1996), ed. Benjamin Lellouch and Stéphane Yerasimos (Paris: L'Harmattan, 1999), 99-131.

96 ASVe, SDC, filza 58, fol. 336r (dated February 3, 1604).

97 Sâfî, Zübdetü't-tevârîh, 2:23-24; and ASVe, SDC, filza 60, fol. 151r (dated November 14, 1604). 
Concerning future affairs, I cannot write with exact knowledge, because it reposes in the infinite Divine wisdom, but for that which I understood of these things that happen daily [...], I cannot say other than that the death of Sultan Mehmed will be extremely damaging to Christendom and, particularly, to Your Serenity, to which I am certain that he had the best inclination, and the reason for this was that, when living, he saw clearly the deterioration of this empire due to the important disorders that through his fault arose, as I could recount at length. And yet one can expect the same thing also from this new Sultan for different reasons, and in particular due to his age as he is not capable of either commanding or ruling by himself, so that it is necessary for him to depend on others. ${ }^{98}$

In the absence of an institutionalized regency in the Ottoman dynastic establishment, Handan Sultan and Mustafa Efendi, as the only figures physically close to the sultan in the palace, became de facto regents and helped Ahmed gradually construct his personal rule in relatively few years.

Handan Sultan's role as regent can be seen in her actions immediately after her son's enthronement, notably in the aforementioned expulsion of Safiye Sultan from the palace on January 9, 1604. Safiye was a truly very powerful queen-mother who exercised overwhelming control over court politics throughout the entire reign of Mehmed III. As a result, she became the target of the imperial sipahis and their supporters, whose above-noted rebellions in the early 1600 s aimed at minimizing or eliminating her faction's political dominance. Although the rebellion of 1603 had significantly curbed the power of Safiye's faction by taking the life of Gazanfer Agha, she soon managed to regain her influence and wielded it until the end of her son's reign..$^{99}$ In one of his unpublished reports, Contarini writes that as of December 20, 1603, a day before Mehmed III's unexpected death, the sipahis were preparing another rebellion against the sultan and his mother. According to the bailo,

The sipahis, who continually return from Hungary, comport themselves poorly, and as poor wretches, it appears almost impossible that this winter will pass without some great uprising, since they keep murmuring against the Queen-mother, and [this grumbling] also began to spread further, mentioning the person of the Sultan. ${ }^{100}$

Hence, when Ahmed ascended to the throne, it was obvious to both him and his mother that as long as Safiye Sultan remained such an alternative focus of power at the court, they would run the risk of a sipahi rebellion or some equally serious problem. Immediately after his enthronement, therefore, Ahmed ordered (or rather was told to order) the expulsion of Safiye Sultan to the Old Palace, along with all of her servants. ${ }^{101}$ Contarini vividly captures the scene:

98 ASVe, SDC, filza 58, fols. 231v-232r (dated December 21, 1603) [emphasis is mine].

99 See Börekçi, "Factions and Favorites," 48-59.

100 ASVe, SDC, filza 58, fols. 216r-v (dated December 20, 1603).

101 Mehmed bin Mehmed, Nuhbe, 617. 
The Queen mother of Sultan Mehmed left the harem, not to return any more, to the indescribable consolation of everyone, but with infinite tears and wailing from her, which were heard through the streets while she went to the Old Palace in a coach, cursing the sultan and auguring every evil. At the same time, with her left all the other ladies in a great number, who, before leaving, out of disdain, broke all the windows of the rooms where they lived and committed several other serious acts of damage, in such a way that the Grand Vizier [Ali Pasha] entered alone, it being such an unusual occurrence, in order to give orders for repairs. The new Queen [Handan] alone remained in the harem with a few women [...]. Truly this woman [Safiye Sultan] was the origin and cause of not a few troubles, and if her son had lived for some years, she might have continued in this way, putting this Empire in complete disorder. ${ }^{102}$

At the same time, seemingly upon Handan Sultan's demand, Ahmed I replaced the incumbent chief eunuch of the harem, Abdürrezzak Agha, with Cevher Agha. ${ }^{103}$ Abdürrezzak Agha was an important member of Safiye's faction and played a critical role in the execution of Prince Mahmud, as seen above. The young sultan also dismissed Kayış Mustafa Agha, the chief of the eunuchs who guarded the entrance to the palace's third court, from his complementary post of hâsodabaşı (chief of the privy chamber), replacing him with Hadım Gürcü Mehmed Agha. ${ }^{104}$ Contarini reports that Mustafa Agha was in fact secretly following the orders of Safiye Sultan. ${ }^{105}$ The night before Ahmed made his first public appearance by visiting the shrine of Abu Ayyub on January 3, 1604, two important members of the privy chamber, the silahdâr (sword-bearer) and rikâbdâr (stirrup-holder), were similarly expelled from their positions under the pretext of fomenting disorder, and many harem women were

102 ASVe, SDC, filza 58, fols. 295v-296r (dated January 17, 1604).

103 Tezcan, "The Question of Regency," 187, writes that the name of Abdürrezzak Agha's successor cannot be ascertained due to conflicting accounts in narrative sources, which refer to him only at the time of his replacement by El-Hac Mustafa Agha in November 1605. For instance, Mehmed bin Mehmed, Nuhbe, 645 and Ahmed Resmî Efendi, Hamîletü'l-küberâ, ed. Ahmet Nezihî Turan (İstanbul: Kitabevi, 2000), 47 both refer to him as Reyhan Agha. However, Sâfî, Zübdetü't-tevârîh, 1:81, calls him Cevher Agha. Actually, several archival documents indicate that the chief eunuch in question was Cevher, not Reyhan. For example, the aforementioned filori defteri mentions Cevher's appointment as the kızlar ağası (i.e., the chief eunuch of the imperial harem) happened before January 17, 1604. TSMA, D. 34, fol. 235r. Similarly, a register that records the furs given by Ahmed I to his household members and government viziers between December 21, 1603 and April 5, 1608, continuously refers to Cevher Agha as the kızlar ağası from early 1604 until he was replaced by El-Hac Mustafa Agha. TSMA, D. 2025, fols. 6v-8r. Reyhan Agha is not mentioned in either of these sources, and it is certain that Cevher was appointed as the chief eunuch of the harem and the overseer of the imperial foundations after Abdürrezzak Agha's dismissal and that he served in this position until El-Hac Mustafa replaced him. I should note that Ahmed Resmî's collection of biographies of chief harem eunuchs should be used with caution, particularly for the period before the eighteenth century.

104 Tezcan, "The Question of Regency," 187; and TSMA, D. 34, fol. 234v. Once Gürcü Mehmed Agha was appointed chief of the privy chamber, Kayış Mustafa Agha served only as chief eunuch of the palace, as indicated by TSMA, D. 34, fol. 235v: "Mâh-ı mezbûrun fî 22 [25 January 1604] Galata ve Paşa sarayı ve Edirne ağalarına ellişer filori in âm olınub Kapu Ağası Kayış Mustafâ Ağa'ya teslîm."

105 ASVe, SDC, filza 58, fol. 280r (dated January 17, 1604). 
sent away, as well. ${ }^{106}$ In sum, in Tezcan's words, "all of these dismissals and appointments mark a break with the previous personnel at the palace and the court politics of the reign of Mehmed III, in which Ahmed's grandmother Safiye Sultan exercised considerable control."107

Although it is hard to ascertain with any precision whether this break with the past was solely the work of Handan Sultan, there is no doubt that she was heavily implicated in it, given that she had vested interests in the reconfiguration of these positions of influence in the imperial harem, where her son resided. Most importantly, considering the fact that Ahmed did not have a princely household of his own, Handan Sultan needed trustworthy and capable men of service to create a "shield" around Ahmed in order to curb attempts to influence him contrary to her wishes.

The first months of Ahmed's sultanate were critical in this respect as any member of the alternative power groupings in the inner circles of the palace could easily manipulate him with a view toward winning appointment to the newly emerging court. As the co-regent for an underage sultan who had succeeded to the throne without a household, Handan Sultan took it upon herself to shape the nucleus of the royal household by appointing loyal and able men. The above-mentioned changes in palace personnel in the immediate aftermath of Ahmed's succession should be considered in this context.

Accordingly, Handan Sultan began building up her network of clients, just as Safiye Sultan had done in the recent past. As co-regent, moreover, Handan was actively involved in the running of dynastic and imperial affairs together with Mustafa Efendi. Furthermore, she favored her fellow Bosnians in appointments to her son's new court.

The appointment of Yavuz Ali Pasha to the grand vizierate sheds light on Handan's political role and influence as regent. As noted earlier, Ali Pasha was of Bosnian origin. According to a contemporary work written about his governorship of Egypt, he was recruited at a young age through the devşirme and then trained at the palace school at Galata for twelve years. In 1583, upon graduation, he was assigned to Prince Mehmed (III)'s service when the latter was about to set out for Manisa following his circumcision festival. In short time, Ali became the sword-bearer as well as a close confidant of Mehmed, who was reportedly very impressed by his servant's unmatched martial skills, especially in archery. ${ }^{108}$

After Mehmed III ascended the throne, he kept Ali as his sword-bearer for six more years, instead of appointing him to an outer post soon after his succession as had been traditionally done by newly enthroned sultans. In this capacity, Ali participated in Mehmed

106 ASVe, SDC, filza 58, fol. 255r (dated January 3, 1604). I was not able to ascertain the name of Ahmed's new stirrup-holder, but his new sword-bearer was Hüseyin Agha, the brother of Nahınî Hasan Pasha, who was executed together with Gazanfer and Osman Aghas in January 1603. See TSMA, D. 34, fol. 234r; and Mehmed bin Mehmed, Nuhbe, 630.

107 Tezcan, "The Question of Regency," 187-188.

108 See Soner Demirsoy (ed.), Vekāyi'-i ‘Ali Paşa [Yavuz Ali Paşa’nın Mısır Valiliği (1601-1603)] (İstanbul: Çamlıca Yayınları, 2012), 333-340. 
III's aforementioned imperial campaign of 1596 and displayed great bravery, especially in protecting his master in the most challenging moments of the battle at Mezőkeresztes. Ultimately, in 1601, the sultan decided to reward his long-time trusted servant with one of the most prestigious appointments, that of governor of Egypt, which Ali held for just over two years. He then succeeded Yemişci Hasan Pasha as grand vizier.

Yemişci Hasan was dismissed and executed in October 1603. Although the majority of contemporary Ottoman chronicles claim that Ali Pasha was appointed to the grand vizierate by Mehmed III around this time, there is credible evidence that the sultan did not, in fact, fill the post. This problem has been discussed at some length by Tezcan, who reaches the tentative conclusion that it was actually Ahmed I who appointed Ali Pasha. ${ }^{109}$ In other words, Tezcan is of the opinion that, at the time of Ahmed's enthronement, there was no acting grand vizier. I would second Tezcan's conclusion by presenting more concrete evidence to this effect while arguing that Handan Sultan had a critical role in Ali Pasha's selection.

First of all, as Tezcan meticulously delineates, Ali Pasha left Egypt for Istanbul on September 13, 1603, before Yemişci Hasan's dismissal, in order to deliver Egypt's tribute, which for the previous two years could not be sent to Istanbul because of the Celâli turmoil in Anatolia. The tribute amounted to 1,200,000 gold ducats. He took the land route via Damascus, accompanied by some 4,000 soldiers, as well as fifteen cannons. As Tezcan aptly notes, had Ali Pasha received the seal of the grand vizierate while on the road, as some contemporary sources claimed, he could have hurried to the capital, leaving the tribute and his retinue behind. ${ }^{110}$

Indeed, according to the Venetian bailo's dispatch of December 20, 1603, the day Mehmed III died, Ali Pasha was intentionally delaying his arrival in the capital for fear he might be forced to accept the grand vizierate, a dangerous position given the ongoing political, military, social and financial crisis in the empire. Grand Admiral Cigalazade Sinan Pasha, who was sailing back to Istanbul from Alexandria, avoided the capital for the same reason, preferring to stop on the Aegean island of Chios. ${ }^{111}$ In fact, the bailo reports that of all the viziers in Istanbul, only Kasım Pasha, who had recently been promoted to the office of deputy grand vizier as a result of Safiye Sultan's favor, was willing to assume the grand vizierate:

Thus Kasım Pasha, most dependent on the Queen [Safiye] with her favor, aspires and agitates greatly in order to obtain this honor. [However], everything remains more than ever uncertain, and I believe that [...] the well-founded judgment will [soon] regulate this election. ${ }^{112}$

Contarini's observations prove that there was no grand vizier during the last months of Mehmed III, who had been apparently searching for a better candidate than Kasım Pasha for

109 Tezcan, "The Question of Regency," 189-195.

110 Ibid., 191-193.

111 ASVe, SDC, filza 58, fol. 215r (dated December 20, 1603).

112 lbid. 
this important position. ${ }^{113}$ On the day of Ahmed's enthronement, Kasım Pasha, still hopeful, requested a private audience with the young sultan. Yet, his request was refused, most probably because he was known to be a protégé of Safiye Sultan. According to Hasan Beyzade, however, Kasım Pasha was rejected because he failed to acknowledge the high standing of the new sultan's long-time tutor, Mustafa Efendi. As Tezcan notes, "Kasım Pasha did not think of paying his respects to Mustafa Efendi on the day of the enthronement. Later, when he heard that Mustafa Efendi was 'respected, honored, and esteemed' by the sultan, and that Ali Pasha was about to reach the capital, Kasım Pasha regretted his initial failure to recognize Mustafa Efendi and tried to make up for it - but it was too late."114

Meanwhile, the chief gardener Bayram Agha had been dispatched to find Ali Pasha en route and inform him of Ahmed's succession. ${ }^{115} \mathrm{He}$ found him in a location roughly two days from Istanbul and told him to leave the Egyptian tribute behind and hurry to the capital. ${ }^{116}$ According to Mehmed bin Mehmed and Contarini, it was at this point that Ali Pasha was offered the seal of the grand vizierate. ${ }^{117}$ He entered Istanbul on December 28, 1603, a week after Ahmed's enthronement, and assumed the grand vizierate. The Janissaries and the imperial cavalry soldiers received their accession donations (cülûs bahşişi), which amounted to a little more than 1,400,000 gold coins, the same day. ${ }^{118}$ The tribute of Egypt arrived a week later, on January $4,1604 .{ }^{119}$

Why did Yavuz Ali Pasha change his mind and accept the grand vizierate? The root cause seems to be the ethnic-regional solidarity as well as ties of clientage between Ali Pasha and Handan Sultan. As Metin Kunt pointed out in a seminal article, one of the defining features of seventeenth-century Ottoman court politics was solidarity among people from the same

113 As Tezcan, "The Question of Regency," 191, aptly notes, such a long delay in appointing a new grand vizier was not unprecedented in Ottoman history: In 1580, after the death of the grand vizier Semiz Ahmed Pasha, Murad III refused for over three months to name a replacement, eventually appointing Koca Sinan Pasha.

114 lbid., 196.

115 The name of the chief gardener at the time of Ahmed's enthronement should be Bayram Agha, not Behram, as argued by Murat Yıldız, "Osmanlı Devlet Teşkilâtında Bostancı Ocağı” (PhD diss., Marmara Üniversitesi, 2008), 274, 276 and 287, based on the salary register, T.C. Cumhurbaşkanlığı Devlet Arşivleri Başkanlığı, Osmanlı Arşivi Daire Başkanlığı [BOA], MAD D. 16332, at 91. Yıldız misreads the name Bayram, which in siyâkat script is almost identical to Behram. Bayram Agha is mentioned as Ahmed's first chief gardener in TSMA, D. 2025, fol. 4v (February 1604) and in BOA, A.DVN, Dosya: 19/55 (dated May-June 1606).

116 According to Mehmed bin Mehmed, Nuhbe, 613, Ali Pasha was two menzils away from the capital, camping near a place called Dil. Generally speaking, a one-day trip was required to go from one menzil to another in the early modern Ottoman road system.

117 Mehmed bin Mehmed, Nuhbe, 613; and ASVe, SDC, filza 58, fol. 232r (dated December 21, 1603).

118 Mehmed bin Mehmed, Nuhbe, 613-616, claims that a total of 700,000 gold coins were distributed to the soldiers as their accession bonus, whereas the register of the sultan's personal treasury gives the exact amount as 1,410,000 (141 kise). See TSMA, D. 34, fol. 234r. For a discussion of the accession donatives between 1574 and 1687, see Murphey, Exploring Ottoman Sovereignty, 126-139.

119 Tezcan, “The Question of Regency," 192-193. 
ethnic-regional background, generally known as cins. ${ }^{120}$ According to Kunt, a major factor in shaping the career of an individual who joined the Ottoman court was his ethnic and/or regional origin and his relations with others of the same background in the Ottoman body politic. Kunt also insightfully observed that this sort of solidarity bred a bipolar antagonism within the Ottoman administrative hierarchy between "westerners," such as Bosnians, Albanians and other Balkan peoples, and "easterners," such as Abkhazians, Circassians, Georgians and other people from the Caucasus. ${ }^{121}$ However, as Jane Hathaway has demonstrated, this kind of east-west antagonism was not limited to court circles in Istanbul but can be observed in Ottoman Egypt and Yemen in the seventeenth century. ${ }^{122}$

In short, when Ali Pasha came back to Istanbul, he found not only a teenage new sultan sitting on the throne, but also a new queen-mother who was of Bosnian origin like himself. Besides, the pasha had long known Ahmed I and Handan Sultan, and vice versa, as explained earlier. These factors no doubt encouraged Ali to accept the grand vizierate, for he could rely on the support of his fellow Bosnian in influencing the decisions of the young sultan, who desperately needed a competent grand vizier to manage the crisis in imperial affairs until he could acquire a personal grasp of the business of rule. Likewise, it is clear that both Handan Sultan and Mustafa Efendi considered Ali Pasha the best candidate to fill the vacuum in the imperial government and that they advised Ahmed to appoint him. Contarini writes that Ahmed followed the inclination not only of his late father, but also "of the greater part of those in the palace" in choosing Ali Pasha as his first grand vizier. ${ }^{123}$

Ali Pasha was a promising candidate in this respect as he had proved himself a rigorous and successful administrator in Egypt. ${ }^{124} \mathrm{He}$ had similarly proved himself a loyal and brave servant of the sultan by safely bringing the tribute of Egypt through Celâli-infested Anatolia. Ali Pasha thus began his grand vizierate with the full support of Ahmed I and his regents. One of his first acts was to rid the administration of officeholders appointed by Safiye Sultan. Indeed, according to the Venetian bailo, "for there being so many elections, it is understood that the Grand Vizier [Ali Pasha] kept changing everything because everything depended on him and it appears that he kept demoting those who were dependents of the Queen-mother

120 Metin Kunt, "Ethnic-Regional (Cins) Solidarity in the Seventeenth-century Ottoman Establishment," International Journal of Middle East Studies 5 (1974), 233-239.

121 Ibid., pp. 237-238.

122 See Jane Hathaway, A Tale of Two Factions: Myth, Memory and Identity in Ottoman Egypt and Yemen, (Albany: State University of New York Press 2003), 42-44 and 181-184.

123 ASVe, SDC, filza 58, fol. 266v (dated January 3, 1604).

124 For a contemporary account of Ali Pasha's administration in Egypt, see Vekāyi'-i 'Alî Paşa. This chronicle written in verse was initially thought to be entirely the work of one Kelâmî, but recent studies establish that it is actually a compilation of various poems written by diverse authors about Ali Pasha while he was the governor of Egypt. See Cihan Okuyucu, “Vekôyii'-i 'Ali Paşa'nın Edebi Değeri," in Vekāyi'-i 'Ali Paşa, xxvii-lxvii. Also see Selçuk Seçkin, “17. Yüzyılın Önemli Minyatürlü Yazması: Vekayi-i “Ali Paşa," Ankara Üniversitesi Osmanlı Tarihi Araştırma ve Uygulama Merkezi Dergisi 21 (2009), 95-122. 
of Sultan Mehmed."125 However, Ali Pasha's vizierate was short-lived: he died in Belgrade in July 1604 while on his way to resume command of the imperial army against the Habsburgs. ${ }^{126}$

Derviş Agha, who replaced the above-mentioned Bayram Agha as chief gardener in the summer of 1604, was another prominent Bosnian protégé of Handan Sultan. Thanks to Handan's continuous support, Derviş managed to become the first royal favorite of Ahmed I, as well as circumvent the traditional patterns of promotion through court ranks and quickly rise to the grand vizierate in 1606. It is commonly reported that it was Ali Pasha who had appointed Derviş chief gardener to replace Bayram Agha, who had failed to execute the deputy grand vizier, Kasım Pasha, whom Ali Pasha suspected of working to undermine him. ${ }^{127}$ On the other hand, the Venetian bailo Contarini notes that Ali Pasha chose Derviş because he was a fellow Bosnian. ${ }^{128}$ In general terms, there was nothing unusual in this choice since Derviş was already the second-highest-ranking gardener in the corps. Moreover, given the pattern of promotions by the end of sixteenth century and the ethno-regional solidarity among Ottoman grandees, it was natural for Ali Pasha to replace the dismissed chief gardener with his fellow Bosnian. ${ }^{129}$

The operative question, then, is not how Derviş Pasha became chief gardener but how he managed to keep this position while becoming a royal favorite during a politically unstable period in which frequent dismissals, resulting from factional struggles or simply from personal enmities, were the norm. His resilience is all the more remarkable when we consider that he soon lost his initial patron, Ali Pasha, in July 1604. The grand vizierate then passed to Lala Mehmed Pasha, an experienced vizier known for his successes during the Long War, whom Derviş reportedly disliked.

Handan Sultan now emerges as the main force behind the solidification of Derviş Agha's status. Contemporary sources reveal that Handan had also encouraged her son to appoint Derviş Agha chief gardener while urging him to rely on Derviş's guidance in the business of rule. The renowned seventeenth-century chronicler Ibrahim Peçevi relates a story that he heard from Derviş's younger brother, Civan Bey, who was a gardener in the palace at that

125 ASVe, SDC, filza 59, fol. 69v (dated March 27, 1604).

126 For a short biography of Yavuz Ali Pasha, see s.v. "Yavuz Ali Paşa," by Somer Demirsoy, DiA, vol. 43:352-353 and Mehmed bin Mehmed, Tarîh, 36-37. On Ali Pasha's appointment as commander-in-chief against the Habsburgs and Ahmed I's related royal writ, see Fatih Bayram, "Sultan I. Ahmed Tarafindan Sadrazam Malkoçoğlu Ali Paşa'ya Tevcih Edilen Engürüs Seferi Serdarlığı Beratı," Dîvân Disiplinlerarası Çalışmalar Dergisi 44 (2018), 91-114.

127 Tarîh-i Peçevî, fol. 292b; and Hasan Bey-zâde Târîhi, 3:813.

128 ASVe, SDC, filza 59, fols. 163v-164r (dated June 5, 1604). Ottoman palace gardeners were often selected from among Bosnian devşirme recruits because of their height and physical strength. Özcan, "Bostancı," DiA.

129 Until the turn of the seventeenth century, a chief gardener was typically promoted to the post of master of the stables, agha of the janissaries or head of the palace gatekeepers (kapucıbaşı). He might then serve in the provincial administration as a district governor (sancakbeyi) or governor-general (beylerbeyi), followed by a vizierate in the central government. See Yıldız, "Osmanlı Devlet Teşkilâtında Bostancı Ocağı," 302-327, for a discussion of the career patterns of chief gardeners with a chronology of appointments in the sixteenth and seventeenth centuries. 
time. ${ }^{130}$ According to Civan, whenever Handan Sultan, Ahmed I and Derviş Agha got together in the palace gardens, the queen-mother "would get her son to swear, by her right as a mother and the milk of her breast, that he would not do anything contrary to [Derviş Agha's] words and thoughts."131

For a young and inexperienced sultan like Ahmed, such strong words were no doubt persuasive. Indeed, when contemporary Ottoman authors refer to Derviş Agha, they typically call him the sultan's mukarreb (derived from the Arabic root $q-r-b$, "to be close to") to emphasize his position as favorite. They likewise stress that his proximity to the sultan quickly reached such a degree that whatever he told Ahmed, it was always accepted, "even if the whole world thought the opposite." 132 Indeed, only six months after Derviş's appointment, the Venetian bailo testifies to the fact he was "very tight with and always at the ear of the sultan" - thanks to his official duty of controlling the rudder of the royal barge whenever the young sultan rode in it. ${ }^{133}$ Overall, Handan Sultan's role in Derviş's rise and fall was quite decisive: it was during her lifetime that he firmly established himself as the sultan's first royal favorite, and it was soon after her death that he reached the apogee of his political power as a minister-favorite, but then suddenly fell from favor and got executed.

It seems that Handan Sultan initially expected Derviş Agha to act as a personal guardian of the young sultan, whose actions and health alarmed his regents, particularly during the first months of his sultanate. The thirteen-year-old Ahmed was a highly energetic character who, as soon as he took the throne, began spending a great deal of time outside the palace, notably hunting or conducting incognito inspections, regardless of the weather. Handan quickly realized that her son could easily put himself in danger and thus needed to be closely watched, for there was no real alternative for the sultanate except Ahmed's four-year-old brother, Prince Mustafa. In this respect, an incident reported by Contarini is highly revealing and helps us further contextualize the beginnings of the close relationship between Ahmed I and Derviş Agha under the guidance of Handan Sultan.

According to the bailo, in early March 1604, Ahmed spent a full day hunting in cold weather. Late in the day, the young sultan wanted to pursue more game on a nearby mountain, but his companions opposed him:

130 Immediately after his elevation to the grand vizierate, Derviş Pasha rewarded his brother with the governorship of Eğriboz, where Peçevi worked with him on a tax survey.

131 Tarîh-i Peçevî, fol. 300b. Also quoted by Peirce, The Imperial Harem, 237, from Tarîh-i Peçevî, 2 vols. (İstanbul: Matbaa-i Amire, 1281-1283/1864-1866, 2:316. Peirce cites this story to illustrate Handan Sultan's role as regent, but she implies that these gatherings occurred during Derviş Pasha's admiralty, that is, after January 1606. Since Handan died in November 1605, it is clear from Peçevi's account that these gatherings took place when Derviş was still chief gardener.

132 Tarîh-i Peçevî, fol. 292v; and Mehmed bin Mehmed, Nuhbe, 647.

133 ASVe, SDC, filza 60, fol. 143r (dated November 14, 1604) and fol. 254 r (dated January 8, 1605). 
On account of the distance and the late hour, and with the weather threatening to turn bad, [the sultan] was advised against this [idea] by his head horseman and chief falconer, who agreed that they should not keep him out at night to his great inconvenience and discomfort. They pointed out these difficulties. His Majesty did not respond with any words; rather he immediately turned his horse and returned to the Barge. Upon reaching the Palace, he immediately sent an order to the Grand Vizier [Ali] to replace the two aforementioned men with other servants, showing with this act the greatest change of heart, so that he displeased many, appearing through this to give some indication of not wanting so easily to accept the opinion or advice of another. He was all the more displeased since the words of these two [servants] were on the order of the Grand Vizier, who had given a command that was to have been made known to the sultan whenever he encountered some similar difficulty that could have a detrimental effect, such as going at night to a mountain with a great retinue where there was neither lodging nor provision of any kind and where there was no time to make preparations, with other circumstances that threatened inconvenience. ${ }^{134}$

By "detrimental effect," Ali Pasha was surely alluding to the precarious situation of the dynasty. Had something happened to the young sultan during these hunts, such as serious injury or accidental death, not only the dynasty but the whole political order, which was already under considerable pressure because of the ongoing wars and rebellions, would have fallen into chaos. We can assume, in any case, that Handan Sultan was ultimately responsible for this order. As noted above, during this early period in Ahmed's sultanate, Ali Pasha was working closely with the queen-mother and the co-regent, Mustafa Efendi, and no doubt they had discussed the best course of action to prevent Ahmed from harming himself so long as they could not stop him from spending so much time outside the palace.

While the queen-mother and her co-regent were cautious in safeguarding the young sultan, an unexpected threat suddenly hit the House of Osman in late March 1604 and brought the dynasty's fragile male line to the brink of extinction: Ahmed and his small half-brother Mustafa contracted smallpox at the same time! Fortunately, both recovered, but it later became publicly known that Ahmed's condition had been so grave that some observed certain indications that "pointed to him dying or at least to his being dangerously ill."135 The prospect was so horrifying that, according to the contemporary chronicler Hasan Beyzade, the members of the government and the court altogether "lost their minds and were near death from fear

134 ASVe, SDC, filza 59, fols. 4r-5r (dated March 9, 1604). The bailo further notes that the chief falconer in question was Halil Agha, the younger brother of the aforementioned royal favorite of Murad III, Doğancı Mehmed Pasha, and that Halil quickly returned to favor, thanks to the intercession of his patrons, Yavuz Ali Pasha and Cigalazade Sinan Pasha.

135 ASVe, SDC, filza 59, fol. 68r (dated March 27, 1604). 
and anxiety."136 It is not hard to imagine Handan Sultan in this picture, especially how deeply worried she must have felt during those days when her young son was bedridden with such a fatal disease of the time.

As Ahmed barely survived smallpox, ensuring the young sultan's safety and wellbeing should have become all the more critical to dynastic continuity. Yet, as soon as Ahmed recovered, he resumed hunting as vigorously as ever. Handan Sultan now desperately needed a trustworthy, able and vigilant servant who could keep an eye on her son whenever he was out of her sight. As the sultan's personal safety during his outings was among the responsibilities of the chief gardener, Derviş Agha was the perfect candidate for this duty. Accordingly, he began to accompany his teenaged master like a shadow, if not like an "outdoor regent." The Venetian bailo observes that Ahmed and Derviş regularly made inspections together in the markets and streets of the capital, punished the wrongdoers whenever they found them, sailed together in the royal barge, and, above all, frequently left the capital to go hunting together. ${ }^{137}$ Handan Sultan's above-mentioned insistence that her son always follow Derviş's advice should also be considered in this context.

However, Handan's early death in November 1605 deprived Derviş Agha of his chief royal patron and led eventually to the dissolution of his own faction in the imperial government. He was executed in December 1606 after holding the grand vizierate for only a few months. ${ }^{138}$ Overall, Handan Sultan's network of clients and patronage was critical in shaping practical politics during Ahmed's early reign.

Until her death, Handan Sultan also took an active part in the management of governmental affairs. Unlike contemporary Ottoman sources, which hardly mention Handan Sultan before her death, the Venetian bailo's reports often describe her political actions in some detail. For instance, some of Contarini's reports indicate that Handan maintained a close relationship with Ali Pasha, especially during the first critical months of Ahmed's sultanate. According to the report dated February 3, 1604, for example, she summoned him to her harem quarters at midnight to discuss current affairs at length. At this secret meeting, Handan Sultan stood behind shutters while Ahmed spoke to the grand vizier face-to-face. As Contarini notes, this was an unprecedented arrangement that touched off a scandal in court circles. Such close contact strongly suggests that Ali Pasha was in fact Handan's client. ${ }^{139}$

136 Hasan Bey-zâde Târîhi, 3:811. For further discussion of this topic, see my "Smallpox in the Harem: Communicable Diseases and the Ottoman Fear of Dynastic Extinction during the Early Sultanate of Ahmed I (r. 1603-17)," in Plague and Contagion in the Islamic Mediterranean, ed. Nükhet Varlık (Kalamazoo, MI: ARC Humanities Press, 2017), 135-152.

137 For example, see ASVe, SDC, filza 60, fol. $224 r$ (dated December 13, 1604); and filza 61, fol. 19r (dated March $14,1605)$.

138 For a detailed discussion of Derviş Pasha's grand vizierate and fall from Ahmed's favor, see Börekçi, "Factions and Favorites," 199-233.

139 ASVe, SDC, filza 58, fols. 338v-339r (dated February 3, 1604). Here, the bailo states that Ahmed had shown his sovereign will through the person of Ali Pasha. 
Furthermore, Handan Sultan acted as an intermediary between her son and other government viziers. According to Ottaviano Bon, who replaced Contarini as bailo in late 1604, as of December 1604, any vizier who wanted to communicate with Ahmed I had to submit his petition first to the queen-mother. It is thus clear that by this time, Handan Sultan had significantly increased her authority over her son as well as her power at court as the queenmother regnant. Still, she was aware of the possible repercussions of such political actions. In Bon's words,

The Queen-mother is growing in authority with the Sultan every day, for which one often sees of being with His Majesty, and the Pashas and other grandees who refer to her in all the things that they want from the Sultan. But she became aware and was instructed of the evil of the Former Queen [Safiye Sultan] that she went embracing the favor little by little in order to establish herself greatly and did not hear well of being new in this concept, because of the tender age of the Sultan, but one believes that one could be successful as any, and perhaps superior to the other. ${ }^{140}$

Yet, by the second year of his sultanate, Ahmed I was struggling to achieve a more independent rule devoid of his mother's regency or watchful eyes. After his second son, Prince Mehmed, was born in March 1605, he took some concrete steps towards this end. His main concern at the time was to prove himself as warrior sultan, thus join the ongoing war in Hungary - just like his late father had done at the beginning of his reign as seen above.

In early October 1605, Ahmed made a spontaneous trip to Edirne, the former Ottoman capital. This was his first long journey outside Istanbul, by means of which he apparently wanted to test his readiness for a campaign march as Edirne was the first major Ottoman military halting station (menzil) on the imperial campaign route westwards. Moreover, Ahmed was personally very attracted to Edirne, not only because of its famous royal hunting preserves replete with all kinds of game, but also because the city was a favorite destination of Süleyman I, Ahmed's role-model ancestor, who had frequently spent his winters there, hunting and preparing for campaigns. ${ }^{141}$ Most importantly, while in Edirne, Ahmed could more quickly receive news about the ongoing siege of the fortress of Esztergom (Estergon) by his grand vizier, Lala Mehmed Pasha, to whom he had recently explained that the conquest of this strategically critical fortress was his "most important purpose."142

140 ASVe, SDC, filza 60, fols. 240v-241r (dated December 24, 1604).

141 For Ottoman sultans' hunting expeditions to Edirne in the sixteenth and seventeenth centuries, see Şenol Çelik, "Osmanlı Padişahlarının Av Geleneğinde Edirne'nin Yeri ve Edirne Kazasındaki Av Alanları (Hassa Şikâr-gâh)" in XIII. Türk Tarih Kongresi, Ankara, 4-8 Ekim 1999: Kongreye Sunulan Bildiriler, III. Cilt III. Kısım (Ankara: Türk Tarih Kurumu, 2002), 1886-1903; and İbrahim Sezgin, “Sultan II. Selim'in Edirne ve Av Gezileri," Türk Kültürü Incelemeleri Dergisi 16 (2007), 1-32. On Ahmed l's hunting expeditions and parties in and around Edirne, see Tülay Artan, "Ahmed I's Hunting Parties: Feasting in Adversity, Enhancing the Ordinary," in Starting With Food: Culinary Approaches to Ottoman History, ed. Amy Singer (Princeton: Markus Wiener Publishers, 2011), 93-118.

142 When Ahmed I and Lala Mehmed Pasha met in Istanbul in February 1605, they discussed the ongoing war in Hungary. See Sâfî, Zübdetü't-tevârîh, 2:9. 
Overall, according to the bailo Bon, Ahmed's original plan was to spend part of the winter of 1605-1606 in Edirne hunting like Süleyman I. He would then gather an army and proceed to Belgrade, where he would join the imperial army under Lala Mehmed Pasha. With this larger army, he could put pressure on the Habsburgs to sign a peace treaty. ${ }^{143}$ For young Ahmed, who wished to be constantly on the move and who had already expressed his desire to fight the Habsburgs, Edirne represented all the things he valued.

Ahmed undertook this trip in a very unusual and even dangerous way. According to contemporary sources, while he was hunting in Çatalca, a menzil town close to Istanbul, he secretly gathered a few of his servants and, without informing anybody in the government or palace, headed to Edirne, a ride of at least five or six days. This impromptu departure naturally worried Handan Sultan and Mustafa Efendi, as well as the viziers and other grandees back in the capital, who were concerned about the young sultan's safety since he was traveling without sufficient guards or logistical support. Notwithstanding, Ahmed completed the journey in only three days without any problem and was welcomed by the townspeople. ${ }^{144}$

In Edirne, Ahmed held court mostly in person in order to deliver sultanic justice and redress the complaints of the people. For instance, he ordered the execution of a number of bandits and punished several other wrongdoers in and around the city. Eight days after his arrival, however, he received a message from Istanbul urging him to return: Nasuh Pasha, who was recently entrusted with the command of the government forces against the Celâlis under the leadership of Tavil Halil, had just suffered a crushing defeat near Bolvadin close to Bursa. ${ }^{145}$ Furious, Ahmed cancelled his war plans and started back. Although he ordered an ostentatious military procession to accompany his re-entry into the capital, as if he had been on a real campaign, the number of soldiers present in Istanbul was, as the Venetian bailo Bon reports, insufficient since most were deployed to various fronts. ${ }^{146}$ Hence Ahmed re-entered the capital with only a limited number of troops on October 17, 1605. ${ }^{147}$

Watching this rather unimpressive procession, Bon noticed that Ahmed had matured: he had gained weight and wore a more serious expression, which the bailo interpreted as a reflection of his rigorous nature. ${ }^{148} \mathrm{Here}$, the bailo seems to be alluding to Ahmed's recent decisions to execute the deputy grand vizier, Sarıkçı Mustafa Pasha, in January 1605, and the governor-general of Damascus, Sinanpaşaoğlu Mehmed Pasha, in August 1605. Indeed, upon

143 ASVe, SDC, filza 62, fols. 90v-91r (dated October 8, 1605).

144 Ahmed l's arrival in Edirne is depicted in a unique miniature included in the poetry collection of Ganizade Nadiri, who was the judge of Edirne during Ahmed's visit: Dîân-ı Nâdirî, fol. 10a. Noteworthy here are Ahmed's youthful, beardless face, the small number of attendants surrounding him, and his extra horse apparently for speed, as well as the presence in the crowd of numerous people waving petitions.

145 Mehmed bin Mehmed, Nuhbe, 644.

146 Interestingly, both Ottoman and Venetian sources refer to this impromptu trip as a campaign. See Sâfî, Zübdetü'ttevârîh, 2:148-149; and ASVe, SDC, filza 62, fols. 90r-91r (dated October 8, 1605).

147 Mehmed bin Mehmed, Nuhbe, 644; and ASVe, SDC, filza 62, fol. 104r (dated October 20, 1605).

148 ASVe, SDC, filza 62, fol. 104 r (dated October 20, 1605). 
Mustafa Pasha's execution, Bon wrote:

One clearly sees that the Grandees who nowadays rule this gate [i.e., government] will always remain with death on their lips [i.e., at their throats], as they are subject to the will of a young Sultan who is impressionable, hot-tempered, bloodthirsty and reckless, and who does not know anything of the world. And he believes himself to be the sole Monarch and that the other Princes [in the world] are lordlings of little account and little property, because there is no one who dares to speak with and tell him of the situation and conditions. Instead, everyone fawns upon him and takes him for a God on earth. ${ }^{149}$

Ahmed developed such a brutal, intolerant and hot-tempered personality that, on the one hand, it proved all the more difficult to control him, and one the other, he became more susceptible to manipulations. The young and restless sultan truly believed that he was destined to rule a great empire, just as his illustrious great-grandfather Süleyman I had. According to a contemporary European account, at the commencement of his reign, Ahmed promised his people that he would create an empire more prosperous than ever before, "by imitating the virtues of his predecessor Süleyman." ${ }^{150}$ Similarly, a foreign author in Istanbul remarked in a letter to a Jesuit priest that Ahmed wanted to become the next Süleyman the Magnificent. ${ }^{151}$ Two years into his sultanate, however, the Ottomans had enjoyed no successes in the costly wars against the Habsburgs and Safavids, nor had the incessant Celâli rebellions in Anatolia ceased. As these multi-front wars were exhausting his empire's revenues and manpower while taking a staggering toll on his subjects, news arrived from Egypt that rebellious soldiers had murdered the governor Hacı İbrahim Pasha, the successor of Yavuz Ali Pasha. The factional struggles among Ahmed's ruling viziers only exacerbated the general political instability. In these precarious circumstances, the young sultan became increasingly intolerant of any mishandling of affairs by his ruling grandees.

In this context, Ahmed's decision to execute Sinanpaşaoğlu Mehmed Pasha marked a turning point in the young sultan's character development as well as in his attempts to free himself from the overwhelming control of his regents, particularly his mother's. Mehmed Pasha was the son of Koca Sinan Pasha, the famous five-time grand vizier in the 1580s and 1590s. In the early 1600 s, Sinanpaşaoğlu became a controversial figure as he was connected to the first major Celâli rebellion led by Karayazıcı. In the summer of 1605, the recently appointed field marshal of the eastern front, Cıgalazade Sinan Pasha, had Sinanpaşaoğlu imprisoned

149 ASVe, SDC, filza 60, fols. 289v-290r (dated January 20, 1605): "si vede chiaro, che li Grandi che oggidi governano a questa porta hanno le teste di vetro, perché stanno sempre con la morte alla gola, sottoposti alla volontà di un Re giovane di gran impressione, collerico, sanguinolente, et precipitoso, che non sa cosa alcuna del mondo, et crede esser Monarca solo, et che gli altri Principi siano come signorotti di poco conto, et di poco havere, perché non è chi ardisca parlar con lui, et li dica 'l stato, et le conditioni d'altri, ma tutti l'adulano, et lo pongono per un Dio in terra."

150 Nebahat Avcıoglu, "Ahmed I and the Allegories of Tyranny in the Frontispiece of George Sandy's Relation of a Journey," Muqarnas 18 (2001), 203-226 at 218.

151 Ibid., 219. 
in the citadel of Aleppo on the grounds that the pasha and his army were acting like Celâlis against the townspeople and peasants. ${ }^{152}$ However, once news of his imprisonment reached the court, Handan Sultan immediately interceded on his behalf and secured his release.

The reason why the queen-mother got involved in this affair in the first place was that Sinanpaşaoğlu Mehmed was the son-in-law of Gevherhan Sultan, thus an important figure within her larger network of clients or allies. ${ }^{153}$ Accordingly, the pasha was recalled to the capital to resume his post as third-ranking vizier on the imperial council. No sooner had he taken his seat in the imperial council, however, than he was summoned to the Chamber of Petitions by Ahmed, who ordered him decapitated before his eyes, explaining, "My pardon permitted him to return to his place in the council; he returned and received his punishment!"154

According to the contemporary Ottoman chroniclers, Handan Sultan, already ill at the time, was so shocked by this turn of events that her condition reportedly worsened, and she died a few months later on November 9, 1605. ${ }^{155}$ She was still in her thirties. After her funeral, Handan Sultan was buried next to her late husband in the royal mausoleum complex nearby Hagia Sophia. With the queen-mother's death, the primary role of controlling the affairs of the imperial harem passed to the recently appointed chief harem eunuch, El-Hac Mustafa Agha, who would shape court politics as the most powerful favorite of Ahmed I in the coming years. ${ }^{156}$

As for her co-regent, Mustafa Efendi, his influence on significant political decisions made by Ahmed I continued as before. The royal tutor's regency is actually more visible than that of the queen-mother. Contemporary sources typically portray him as an advisor to the young sultan, who frequently heeded his tutor's counsel. According to Contarini, for example, Mustafa Efendi assumed his role as regent immediately after Ahmed's enthronement while attempting to hold sway over him:

152 See Börekçi, "Factions and Favorites," 35 and 39-41.

153 Bon writes that Handan Sultan had actually acted on the letter written to Gevherhan Sultan by her daughter, asking help to save her husband Sinanpaşaoğlu. ASVe, SDC, filza 62, fol. $26 \mathrm{v}$ (dated September 10, 1605). This still unidentified wife of Sinanpaşaoğlu was one of the daughters of Gevherhan Sultan from her first husband, Piyale Pasha. The couple was married in November 1598 during the grand vizierate of Cerrah Mehmed Pasha and their wedding was celebrated by a public festival. See Tarih-i Selânikî, 2:771 and 777-779.

154 Quoted by Peirce, The Imperial Harem, 243. However, Peirce is mistaken when she claims that Sinanpaşaoğlu was executed in 1603.

155 Mehmed bin Mehmed, Nuhbe, 643-644; and Hasan Bey-zâde Târîhi, 3:873. Unfortunately, none of the available sources indicate the exact cause of her death or what kind of a health problem she had.

156 On El-Hac Mustafa Agha's power and influence as the royal favorite of Ahmed I, see Börekçi, "Factions and Favorites," 242-254; Elma Korić, "Power Broker at the Ottoman Palace in Istanbul: Darüssaade Ağası Hacı Mustafa Ağa," in V. Uluslararası Osmanlı İstanbulu Sempozyumu Bildirileri (27-29 Mayıs 2017), ed. Feridun Emecen, Ali Akyıldız and Emrah Safa Gürkan (İstanbul: İstanbul Büyükşehir Belediyesi Yayınları, 2018), 811-834; and Jane Hathaway, Chief Eunuch of the Ottoman Harem, esp. 77-97. 
It appears that his Coza [Hoca], or tutor, keeps regulating and advising him in all his actions. This Coza was present when the Mufti and the Viziers were summoned to the Kiosk for a certain consultation called by him so that he might have great authority over this prince, being an old man and reputed to be prudent. ${ }^{157}$

Indeed, Mustafa Efendi's position and power grew bolder every day. As Tezcan has already discussed, he had a profound influence on the young sultan, notably prompting Ahmed's decisions to force Yavuz Ali Pasha to lead the army to the Hungarian front in person, despite the pasha's desire to remain in Istanbul; to appoint Hadım Hafız Ahmed Pasha to the deputy grand vizierate instead of Sofu Sinan Pasha, who was Yavuz Ali's choice; to dismiss the mufti Ebülmeyâmin Mustafa Efendi, the royal tutor's chief rival; to appoint Lala Mehmed Pasha to the grand vizierate in August 1604; to execute the Deputy Grand Vizier Sarıkçı Mustafa Pasha in January 1605; and to recall the Grand Vizier Lala Mehmed Pasha from Belgrade to Istanbul in the first months of $1606 .{ }^{158}$ Yet considering the co-regency of Handan Sultan, it would be erroneous to assume that Mustafa Efendi was the sole advisor or regent for Ahmed in making the above-mentioned decisions. Most likely, she was also consulted in these matters.

Mustafa Efendi's influence was not limited to such decisions, however. He was equally involved in the shaping of Ottoman foreign policy during Ahmed's early reign. For instance, the Venetian bailo Bon reports that Mustafa Efendi convinced the sultan to continue diplomatic relations with England in January 1606, at a time when Ahmed was thinking of breaking them off as a result of increasing English piracy in the Mediterranean. ${ }^{159}$ By the time Mustafa Efendi died in around 1608, however, Ahmed no longer needed a regent since he had managed to establish his personal rule.

\section{Concluding Remarks}

Handan Sultan was no doubt a key figure at the Ottoman imperial court in the early seventeenth century. She played a critical political role during her teenage son's early reign and acted as co-regent together with Mustafa Efendi until her death in November 1605. Furthermore, her network of clients and viziers remained an important component of the faction-ridden politics in the court well after her demise.

Handan Sultan's actions solidified the political power of the queen-mother within the formal as well as informal institutional boundaries of Ottoman court politics. In one sense, her regency set a clear example for future queen-mothers, particularly during the turbulent first half of the seventeenth century, when several more underage sultans took the throne. For instance, Kösem Sultan's active involvement in politics during the reigns of her sons, Murad IV and Sultan Ibrahim, or Turhan Sultan's regency of her minor son Mehmed IV, can easily be compared to Handan Sultan's role as regent. Further comparative studies on the question

157 ASVe, SDC, filza 58, fol. 256v (dated January 3, 1604).

158 Tezcan, "The Question of Regency," 197.

159 Ibid. 
of regency would surely reveal more similarities in the political roles of the Ottoman queenmothers in this general crisis period.

In the preceding pages, I have presented and discussed several historical events/moments, individuals/groups of people and problems/topics all in relation to Handan Sultan's life and career trajectory within the Ottoman dynastic-imperial establishment between 1582 and 1605. But these are essentially life sketches and, if I have succeeded, they offer only some tangible glimpses into what Handan had lived, experienced, endured or achieved in a highly turbulent period of Ottoman history. That is to say, they do not represent the entirety of what we can glean from the existing historical accounts pertaining to Handan's personal agency and various undertakings, particularly during her short queen-mothership. We certainly need further research and new studies, ideally based on a much larger pool of primary sources, in order to develop a fuller biographical profile of Handan Sultan and accordingly to attain a better understanding of her historical standing and significance vis-à-vis other dynastic matriarchs of the House of Osman.

Finally, in all these respects, the unpublished dispatches of the Venetian ambassadors resident in Istanbul prove indispensable for any study of premodern Ottoman ruling elite, and especially for delineating the dynamics and actors of the Ottoman dynastic and court politics from the late sixteenth to the early eighteenth centuries, a critical period when queen-mothers exercised considerable political power and influence in the business of rule. As I have tried to demonstrate, in addition to the available Ottoman archival and narrative sources, these Italian ambassadorial letters contain much critical historical information and sometimes provide us unique perspectives about the previously unknown or poorly documented aspects of the life and actions of a royal mother, besides her reigning son and other ruling grandees of the time. Indeed, thanks to these vigilant Venetian observers of the Ottoman imperial court and its members way back, Handan Sultan, once an obscure slave girl from Bosnia, today reemerges before our eyes as a highly important queen-mother of early seventeenth century.

Peer-review: Externally peer-reviewed.

Conflict of Interest: The author has no conflict of interest to declare.

Grant Support: The author declared that this study has received no financial support.

Hakem Değerlendirmesi: Dış bağımsız.

Çıkar Çatışması: Yazar çıkar çatışması bildirmemiştir.

Finansal Destek: Yazar bu çalışma için finansal destek almadığını beyan etmiştir.

\section{Bibliography}

\section{Archival Sources:}

Archivio di Stato di Venezia, Senato, Dispacci Costantinopoli (SDC), Filze 57, 58, 59, 60, 61, 62.

Topkapı Sarayı Müzesi Arşivi, D. 34, 2025, 7856/2. 
Türkiye Cumhuriyeti Cumhurbaşkanlığı Devlet Arşivleri Başkanlığı, Osmanlı Arşivi Daire Başkanlığı, MAD, D. 16332; A.DVN, Dosya: 19/55.

\section{Unpublished Literary Sources:}

Ganîzâde Mehmed, Dîvân-ı Nâdirî, Topkapı Sarayı Müzesi Kütüphanesi, MS Hazine 889.

Seyyid Lokman, Zübdetü't-tevârîh, Türk İslam Eserleri Müzesi, MS 1973.

Silsile-nâme-i Âl-i ‘Osmân, Milli Kütüphane, MS 06 Hk 11/3.

Talîkīzâde, Şehnâme-i Sultân-ı Selatîn-i Cihân, Topkapı Sarayı Müzesi Kütüphanesi, MS Hazine 1609.

\section{Primary Source Editions:}

ABDÜLKADiR EFENDi. Topçular Kâtibi ‘Abdülkādir (Kadrî) Efendi Tarihi, ed. Ziya Yılmazer. 2 vols., Ankara: Türk Tarih Kurumu, 2003.

AHMED RESMî EFENDi. Hamîletü'l-küberâ. ed. Ahmet Nezihî Turan, İstanbul: Kitabevi 2000.

BERTELLI, Pietro. Vite degl'imperatori de Turchi. [NP], 1599.

Calendar of State Papers and Manuscripts, Relating to English Affairs, Existing in the Archives and Collections of Venice, and in Other Libraries of Northern Italy. 38 vols., London: His Majesty's Stationery Office, 1864-1940.

Calendar of the Manuscripts of the Most Hon. the Marquis of Salisbury, Preserved at Hatfield House, Hertfordshire. ed. Edward Salisbury, 26 vols., London: His Majesty's Stationery Office, 1883-1923.

DURSTELER, Eric. In the Sultan's Realm: Two Venetian Ambassadorial Reports on the Early Modern Ottoman Empire. Toronto: Centre for Reformation and Renaissance Studies, 2018.

HASAN BEY-ZÂDE AHMED PAŞA. Hasan Bey-zâde Târîhi. ed. Nezihi Aykut, 3 vols., Ankara: Türk Tarih Kurumu, 2004.

IBRAHIM PEÇEVÎ. Tarîh-i Peçevî. 2 vols., İstanbul: Matbaa-i Amire, 1281-1283/1864-1866.

LEUNCLAVIUS, Johannes. Türk Milletinin Tarihi. trans. Türkis Noyan, İstanbul: Yeditepe Yayınları, 2019. KÂTiB ÇELEBi. Fezleke. ed. Zeynep Aycibin, 2 vols., İstanbul: Çamlıca, 2016.

Kānûnnâme-i Âl-i Osman: Tahlil ve Karşılaştırmalı Metin. ed. Abdülkadir Özcan, İstanbul: Kitabevi, 2003.

Le relazioni degli ambasciatori veneziani al senato durante il secolo decimosesto. ed. Eugenio Albèri, serie 3, vol. III, Florence: Società editrice fiorentina, 1855.

MEHMED BIN MEHMED. Nuhbetü't-tevârîh ve'l-ahbâr and Târîh-i Âl-i Osmân. ed. Abdurrahman Sağırl, “Mehmed b. Mehmed Er-Rumî (Edirneli)'nin Nuhbetü't-tevârîh ve'l-ahbâr'ı ile Târîh-i Âl-i Osmân'ının Metni ve Tahlilleri." PhD diss., İstanbul Üniversitesi, 2000.

MEHMED SÜREYYA. Sicil-i Osmanî. ed. Nuri Akbayar and Seyit Ali Kahraman, 6 vols., İstanbul: Tarih Vakfı Yayınları, 1996.

MUSTAFA SÂF̂̂. Zübdetü't-tevârîh. ed. İbrahim Hakkı Çuhadar, 2 vols., Ankara: Türk Tarih Kurumu, 2003.

MUSTAFA SELÂNiKÎ. Tarih-i Selânikî. ed. Mehmet İpşirli, 2 vols., Ankara: Türk Tarih Kurumu, 1999 (2nd edition).

ÖZDEMiR, Mehmet. Ferâhî, Sûrnâme: Bir Özge Âlem, Osmanlı Pâyitahtında 1582 Şenliği. Ankara: Grafiker Yayınları, 2016.

Relazioni di ambasciatori veneti al senato, tratte dalle migliori edizioni disponibili e ordinate cronologicamente, vol. 13: Costantinopoli (1590-1793). ed. Luigi Firpo, Torino: Bottega d'Erasmo, 1984.

Relazioni di ambasciatori veneti al senato, vol. 14: Costantinopoli, Relazioni inedite (1512-1789). ed. Maria Pedani-Fabris, Padua: Bottega d'Erasmo, 1996. 
SENECA, Federico. Il Doge Leonardo Donà: la sua vita e la sua preparazione politica prima del dogado. Padova: Editrice Antenore, 1959.

The Report of Lello: Third English Ambassador to the Sublime Porte. ed. Orhan Burian, Ankara: Türk Tarih Kurumu, 1952.

Vekāyi'-i 'Ali Paşa [Yavuz Ali Paşa'nın Mısır Valiliği (1601-1603)]. ed. Soner Demirsoy, İstanbul: Çamlıca Yayınları, 2012.

\section{Secondary Literature:}

ABOU-EL-HAJ, Rifa'at. "The Narcissism of Mustafa II (1695-1703): A Psychohistorical Study." Studia Islamica 40 (1974): 115-131.

AFYONCU, Erhan and Uğur DEMiR. Turhan Sultan. İstanbul: Yeditepe Yayınları 2015.

AKTEPE, M. Münir. "Mustafâ I.” M.E.B. İslâm Ansiklopedisi, 8:692-695.

AKYILDIZ, Ali. Haremin Padişahı Valide Sultan: Harem'de Hayat ve Teşkilat. İstanbul: Timaş Yayınları, 2017.

ALDERSON, Anthony D.. The Structure of the Ottoman Dynasty. Oxford: Oxford University Press, 1956. ARBEL, Benjamin. “Nur Banu (c. 1530-1583): A Venetian Sultana?.” Turcica 24 (1992): 241-259.

ARTAN, Tülay. "Ahmed I's Hunting Parties: Feasting in Adversity, Enhancing the Ordinary." in Starting With Food: Culinary Approaches to Ottoman History, ed. Amy Singer, 93-118. Princeton: Markus Wiener Publishers, 2011.

AVCIOĞLU, Nebahat. "Ahmed I and the Allegories of Tyranny in the Frontispiece of George Sandy's Relation of a Journey." Muqarnas 18 (2001): 203-226.

BAYAT, Ali Haydar. “Edirne Sarayı Sosyal Hayatından Bir Kesit: 861/1457 Sünnet Şenliği." in I. Edirne Sarayı Sempozyumu Bildirileri, ed. Ender Bilar, 62-75. Edirne: Trakya Üniversitesi Rektörlüğü Yayınları, 1996.

BAYAT, Ali Haydar. “Fâtih'in Tertip Ettiği Sünnet Şenlikleri (Sûr-i Hümâyunlar).” Kubbealtı Akademi Mecmuası 3 (1983): 51-62.

BAYAT, Ali Haydar. "Kanûnî’nin Tertip Ettiği Şenliklerden 1539 Sûr-i Hümâyûnu." in Uluslararası Dördüncü Türk Kültürü Kongresi Bildirileri, ed. Azize Aktaş Yaşa and İmran Baba, 3:134 and 461. Ankara: Atatürk Kültür Merkezi Başkanlığı, 2000.

BAYRAM, Fatih. "Sultan I. Ahmed Tarafindan Sadrazam Malkoçoğlu Ali Paşa'ya Tevcih Edilen Engürüs Seferi Serdarlığı Beratı.” Dîvân Disiplinlerarası Çalışmalar Dergisi 44 (2018): 91-114.

BORROMEO, Elisabetta. "Le relazioni degli ambasciatori veneziani presso la Porta Ottomana." Miscellanea di storia delle esplorazioni 19 (1994): 125-154.

BOSTAN, İdris. "Esaretten Vezarete Bir Osmanlı Kaptanıderyası: Piyale Paşa." in Piyale Paşa Camii: 2005-2007 Restorasyonu, ed. Baha Tanman and İdris Bostan, 13-37. İstanbul: Gürsoy Grup Kültür Yayınları, 2011.

BÖREKÇi, Günhan. “İnkırâzın Eşiğinde Bir Hanedan: III. Mehmed, I. Ahmed, I. Mustafa ve 17. Yüzyıl Osmanlı Siyasî Krizi." Dîvân Disiplinlerarası Çalışmalar Dergisi 26 (2009): 45-96.

BÖREKÇI, Günhan. "Factions and Favorites at the Courts of Ahmed I (r. 1603-1617) and His Immediate Predecessors." PhD diss, Ohio State University, 2010.

BÖREKÇi, Günhan. Macaristan'da Bir Osmanlı Padişahı: Sultan III. Mehmed'in Eğri Seferi Rûznâmesi (1596). İstanbul: Metamorfoz Yayınları, 2016.

BÖREKÇI, Günhan. "Smallpox in the Harem: Communicable Diseases and the Ottoman Fear of Dynastic Extinction during the Early Sultanate of Ahmed I (r. 1603-17)." in Plague and Contagion in the Islamic Mediterranean, ed. Nükhet Varlık, 135-152. Kalamazoo, MI: ARC Humanities Press, 2017. 
CANALS, Jordi. “Un informe otomano de Salomón Usque (1595)." Espacio, Tiempo y Forma, Serie IV, H.a Moderna 16 (2003): 153-181.

COCO, Carla and Flora MANZONETTO. Baili veneziani alla Sublime Porta: storia e caratteristiche dell'ambasciata veneta a Costantinopoli. Venice: Stamperia di Venezia, 1985.

ÇELIK, Şenol. “Osmanlı Padişahlarının Av Geleneğinde Edirne'nin Yeri ve Edirne Kazasındaki Av Alanları (Hassa Şikâr-gâh)." in XIII. Türk Tarih Kongresi, Ankara, 4-8 Ekim 1999: Kongreye Sunulan Bildiriler, III. Cilt III. KIsım, 1886-1903. Ankara: Türk Tarih Kurumu 2002.

DARLING, Linda. Revenue-Raising and Legitimacy: Tax Collection and Finance Administration in the Ottoman Empire, 1560-1660. Leiden: Brill, 1996.

DEMIRSOY, Somer. “Yavuz Ali Paşa." Türkiye Diyanet Vakfı Islam Ansiklopedisi, 43:352-353.

DÜNDAR, Recep. “Kıbrıs'ta Sultan Murad Han'ın Validesine (Kösem Sultan) Ait Mülk Çiftlikler.” Karadeniz Araştırmaları: Balkan, Kafkas, Doğu Avrupa ve Anadolu Incelemeleri Dergisi 35 (2012): 111-124.

DURSTELER, Eric. "Fatima Hatun née Beatrice Michiel: Renegade Women in the Early Modern Mediterranean." The Medieval History Journal 12/2 (2009): 355-382.

DURSTELER, Eric. "Describing or Distorting the "Turk"?: The Relazioni of the Venetian Ambassadors in Constantinople as Historical Source." Acta Histriae 19/1-2 (2011): 231-248.

DURSTELER, Eric. "The Bailo in Constantinople: Crisis and Career in Venice's Early Modern Diplomatic Corps." Mediterranean Historical Review 16/2 (2001): 1-30.

EMECEN, Feridun. Imparatorluk Çağının Osmanlı Sultanları-II: II. Selim'den Sultan Ibrâhim'e (1566-1648). İstanbul: ISAM Yayınları, 2016.

EMECEN, Feridun. "Osmanlı Hanedanına Alternatif Arayışlar Üzerine Bazı Örnekler ve Mülahazalar," in idem, Osmanlı Klasik Çağında Hanedan, Devlet ve Toplum, 37-60. İstanbul: Timaş Yayınları 2011.

EMECEN, Feridun. "Osmanlı Şehzadeleri ve Taşra İdaresi." in Selçukludan Cumhuriyete Şehir Yönetimi, ed. Erol Özvar and Arif Bilgin, 99-112. İstanbul: Türk Dünyası Belediyeler Birliği 2008.

EMECEN, Feridun. "Sonucu Olmayan Büyük Zafer: Haçovası Meydan Savaşı." in Savaşın Sultanları: Osmanlı Padişahlarının Meydan Muharebeleri, ed. Coşkun Yılmaz, 2 vols., 2:66-145. İstanbul: Bilge Yayım Habercilik 2018,

ESIR, Hasan Ali. “Eğri Kalesi'nin Fethi ve Haçova Meydan Savaşı'nı Anlatan Fetih-name Türünde Bir Mektup." Çukurova Üniversitesi Sosyal Bilimler Enstitüsü Dergisi 17/2 (2008): 177-190.

FAROQHI, Suraiya. "Crisis and Change." in An Economic and Social History of the Ottoman Empire, ed. Halil İnalcık with Donald Quataert, 411-636. Cambridge: Cambridge University Press, 1997.

FETVACl, Emine. Picturing History at the Ottoman Court. Bloomington: Indiana University Press, 2013.

FINKEL, Caroline. The Administration of Warfare: The Ottoman Military Campaigns in Hungary, 15931606. Vienna: Verband der wissenschaftlichen Gesellschaften Österreichs, 1988.

FLEISCHER, Cornell H.. Bureaucrat and Intellectual in the Ottoman Empire: The Historian Mustafa Âli (1541-1600). Princeton: Princeton University Press, 1986.

FLETCHER, Joseph. "Turco-Mongolian Monarchic Tradition in the Ottoman Empire." Harvard Ukrainian Studies 3-4 (1979-1980): 236-251.

FODOR, Pál. "The View of the Turk in Hungary: The Apocalyptic Tradition and the Legend of the Red Apple in Ottoman-Hungarian Context." in Les traditions apocalyptiques au tournant de la chute de Constantinople: Actes de la Table ronde d'Istanbul (13-14 avril 1996), ed. Benjamin Lellouch and Stéphane Yerasimos, 99-131. Paris: L'Harmattan 1999.

FODOR, Pál. The Business of State: Ottoman Finance Administration and Ruling Elite in Transition (1580s1615). Berlin: Klaus Schwarz, 2018. 
GÜRKAN, Emrah Safa. "Fonds for the Sultan: How to Use Venetian Sources for Studying Ottoman History." News on Rialto 32 (2013): 22-28.

HALAÇOĞLU, Yusuf. “Cerrah Mehmed Paşa.” Türkiye Diyanet Vakfı İslam Ansiklopedisi, 7:415.

HATHAWAY, Jane. A Tale of Two Factions: Myth, Memory and Identity in Ottoman Egypt and Yemen. Albany: State University of New York Press, 2003.

HATHAWAY, Jane. Chief Eunuch of the Ottoman Harem: From African Slave to Power-Broker. Cambridge: Cambridge University Press, 2018.

HEGYI, Klára. "The Financial Position of the Vilayets in Hungary in the 16th-17th Centuries." Acta Orientalia Academiae Scientiarum Hungaricae 61/1-2 (2008): 77-85.

INALCIK, Halil. “Osmanlılarda Saltanat Veraset Usulü ve Türk Hakimiyet Telâkkisiyle İlgisi." Ankara Üniversitesi Siyasal Bilgiler Fakültesi Dergisi 14 (1959): 69-94.

INALCIK, Halil. Devlet-i ‘Aliyye: Osmanlı Imparatorluğu Üzerine Araştırmalar-II: Tagayyür ve Fesad (16031656): Bozuluş ve Kargaşa Dönemi. ed. Emre Yalçın, İstanbul: Türkiye İş Bankası Kültür Yayınları, 2014.

IPŞIRLI ARGIT, Betül. "A Queen-mother and the Ottoman Imperial Harem: Rabia Gülnuş Emetullah Valide Sultan (1640-1715)." in Concubines and Courtesans: Women and Slavery in Islamic History, ed. Matthew S. Gordon and Kathryn A. Hain, 207-224. Oxford: Oxford University Press 2017.

IPŞIRLI ARGIT, Betül. Rabia Gülnuş Emetullah Sultan, 1640-1715. İstanbul: Kitap Yayınevi, 2015.

IPŞIRLI, Mehmet. "Şeyhülislâm Sun'ullah Efendi." İstanbul Üniversitesi Tarih Enstitüsü Dergisi 13 (19831987): 209-256.

KAFADAR, Cemal. "Prelude to Ottoman Decline Consciousness: Monetary Turbulence at the end of the Sixteenth Century and the Intellectual Response." Osmanlı Araştırmaları 51 (2018): 265-295.

KAYAALP, Pinar. The Empress Nurbanu and Ottoman Politics in the Sixteenth Century: Building the Atik Valide. London: Taylor and Francis, 2018.

KIVRIM, İsmail. “17. Yüzyılda Bir Valide Sultanın Günlük Hayatı: Vâlide Hadîce Turhan Sultan.” History Studies 5/2 (2013): 243-262.

KOCAASLAN, Murat. Kösem Sultan: Hayatı, Vakıfları, Hayır İşleri ve Üsküdar'daki Külliyesi. İstanbul: Okur Kitaplı̆̆ı, 2014.

KORIĆ, Elma. "Power Broker at the Ottoman Palace in Istanbul: Darüssaade Ağası Hacı Mustafa Ağa." in V. Uluslararası Osmanlı Istanbulu Sempozyumu Bildirileri (27-29 Mayıs 2017), ed. Feridun Emecen, Ali Akyıldız and Emrah Safa Gürkan, 811-834. İstanbul: İstanbul Büyükşehir Belediyesi Yayınları 2018.

KORKMAZ, Gülsüm Ezgi. “Sûrnâmelerde 1582 Şenliği.” Unpublished MA thesis, Bilkent Üniversitesi, 2004. KUMRULAR, Özlem. Haremde Taht Kuranlar: Nurbanu ve Safiye Sultan. İstanbul: Doğan Kitap, 2017.

KUMRULAR, Özlem. Kösem Sultan: İktidar, Hırs, Entrika. İstanbul: Doğan Kitap, 2015.

KUNT, Metin. "Ethnic-Regional (Cins) Solidarity in the Seventeenth-century Ottoman Establishment." International Journal of Middle East Studies 5 (1974): 233-239.

KUNT, Metin. "A Prince Goes Forth (Perchance to Return)." in Identity and Identity Formation in the Ottoman World: A Volume of Essays in Honor of Norman Itzkowitz, ed. Baki Tezcan and Karl K. Barbir, 63-71. Madison: University of Wisconsin Press, 2007.

KÜPELİ, Özer. “Kösem Sultan'a Ait Bir Muhallefat Kaydı." Cihannüma: Tarih ve Coğrafya Araştırmaları Dergisi 1/2 (2015): 131-143.

LUTERBACHER, Jürg and Elena XOPLAKI. “500-Year Winter Temperature and Precipitation Variability over the Mediterranean Area and Its Connection to the Large-Scale Atmospheric Circulation." in Mediterranean Climate: Variability and Trends, ed. Hans-Jürgen Bolle, 133-153. Berlin: Springer Verlag, 2003. 
MURPHEY, Rhoads. Exploring Ottoman Sovereignty: Tradition, Image and Practice in the Ottoman Imperial Household, 1400-1800. London: Continuum, 2008.

OCAKAÇAN, Levent Kaya. "The Changing Dynamics of the Ottoman Patronage Networks (Late $16^{\text {th }}$ and Early 17th Centuries)." Archivum Ottomanicum 34 (2017): 9-18.

OKUYUCU, Cihan. “Vekâyi'-i ‘Ali Paşa'nın Edebi Değeri." in Vekāyi'-i ‘Ali Paşa, ed. Demirsoy, pp. xxvii-lxvii. ÖZGÜLEŞ, Muzaffer. The Women Who Built the Ottoman World: Female Patronage and the Architectural Legacy of Gülnuş Sultan. London: I.B. Tauris, 2017.

ÖZVAR, Erol. "Osmanlı Bütçe Harcamaları." in Osmanlı Maliyesi: Kurumlar ve Bütçeler, ed. Mehmet Genç and Erol Özvar, 2 vols., 1:197-238. İstanbul: Osmanlı Bankası Arşiv ve Araştırma Merkezi 2007.

PEDANI-FABRIS, Maria Pia. “Veneziani a Costantinopoli alla fine del XVI secolo." Quaderni di Studia Arabi 15 (1997): 67-84.

PEDANI, Maria Pia. “Safiye's Household and Venetian Diplomacy." Turcica 32 (2000): 9-32.

PEIRCE, Leslie. The Imperial Harem: Women and Sovereignty in the Ottoman Empire. Oxford: Oxford University Press, 1993.

REINDL-KIEL, Hedda. "Power and Submission: Gifting at Royal Circumcision Festivals in the Ottoman Empire (16 $6^{\text {th }}-18^{\text {th }}$ Centuries)." Turcica 41 (2009): 37-88.

ROSSI, Ettore. "La Sultana Nûr Bânû (Cecilia Venier-Baffo) moglie di Selim II (1566-1574) e madre di Murad III (1574-1595)." Oriente Moderno 11 (1953): 433-441.

SAĞIR, Yusuf. "Vâlide Turhan Sultan'ın Muhallefâtı." Çanakkale Araştırmaları Türk Yıllığı 20 (2016), 265-328.

SAKAOĞLU, Necdet. Bu Mülkün Kadın Sultanları. İstanbul: Alfa Yayınları, 2015 (revised ed.).

ŞAHIN, Kaya. "Staging an Empire: An Ottoman Circumcision Ceremony as Cultural Performance." American Historical Review 123/2 (2018): 463-92.

SEÇKIN, Selçuk. “17. Yüzyılın Önemli Minyatürlü Yazması: Vekayi-i “Ali Paşa.” Ankara Üniversitesi Osmanlı Tarihi Araştırma ve Uygulama Merkezi Dergisi 21 (2009): 95-122.

SEVINÇ, Tahir. “II. Mustafa'nın İktidar Mücadelesi ve 1703 Edirne İsyanıyla Tahttan İndirilmesi.” Osmanlı Mirası Araştırmaları Dergisi 4/9 (2017): 25-42.

SEZGiN, İbrahim. “Sultan II. Selim'in Edirne ve Av Gezileri.” Türk Kültürü Incelemeleri Dergisi 16 (2007): 1-32.

SKILLITER, Susan A.. “Three Letters from the Ottoman ‘Sultana' Safiye to Queen Elizabeth I.” in Documents from Islamic Chanceries, ed. Samuel M. Stern, 119-235. Oxford: Cassier, 1965.

SKILLITER, Susan A.. "Mehemmed III." Encyclopedia of Islam, $2^{\text {nd }}$ ed., consulted online on June 2, 2020 (https://referenceworks.brillonline.com/browse/encyclopaedia-of-islam-2).

SZALONTAY, Tibor. "The Art of War during the Ottoman-Habsburg Long War (1593-1606) according to Narrative Sources." PhD diss, University of Toronto, 2004.

TERZioĞLU, Derin. “The Imperial Circumcision Festival of 1582: An Interpretation.” Muqarnas 12 (1995): 84-100.

TEZCAN, Baki. "Searching for Osman: A Reassessment of the Deposition of the Ottoman Sultan Osman II (1618-1622)." PhD diss., Princeton University, 2001.

TEZCAN, Baki. “The Debut of Kösem Sultan's Political Career." Turcica 40 (2008): 347-59.

TEZCAN, Baki. “The Question of Regency in the Ottoman Dynasty: The Case of the Early Reign of Ahmed I." Archivum Ottomanicum 25 (2008): 185-98 [published in 2009].

TEZCAN, Baki. The Second Ottoman Empire: Political and Social Transformation in the Early Modern World. Cambridge: Cambridge University Press, 2010. 
THYS-ŞENOCAK, Lucienne. Ottoman Women Builders: The Architectural Patronage of Hadice Turhan Sultan, Burlington, VT: Ashgate, 2007.

TÓTH, Sándor László. A mezőkeresztesi csata és a tizenöt éves háború. Szeged: Belvedere, 2000.

ULUÇAY, Çağatay. Padişahların Kadınları ve Kızları. Ankara: Türk Tarih Kurumu Yayınları, 1985 (2nd ed.).

UZUNÇARŞILI, İsmail Hakkı. “Sancağa Çıkarılan Osmanlı Şehzadeleri.” Belleten 156 (1975): 659-696.

UZUNÇARŞILI, İsmail Hakkı. “Üçüncü Mehmed'in Oğlu Şehzade Mahmud’un Ölümü.” Belleten 94 (1960): 263-267.

VARLIK, Nükhet. Plague and Empire in the Early Modern Mediterranean World: The Ottoman Experience, 1347-1600. Cambridge: Cambridge University Press, 2015.

WOODHEAD, Christine. "Murad III and the Historians: Representations of Ottoman Imperial Authority in Late $16^{\text {th }}$-century Historiography." in Legitimizing the Order: The Ottoman Rhetoric of State Power, ed. Hakan T. Karateke and Maurius Reinkowski, 85-98. Leiden: Brill 2005.

YELÇE, Zeynep. “Evaluating Three Imperial Festivals: 1524, 1530 and 1539." in Celebration, Entertainment and Theatre in the Ottoman World, ed. Suraiya Faroqhi and Arzu Öztürkmen, 71-109. Calcutta: Seagull Books, 2014.

YILDIZ, Murat. “Osmanlı Devlet Teşkilâtında Bostancı Ocağı.” PhD diss., Marmara Üniversitesi, 2008. 